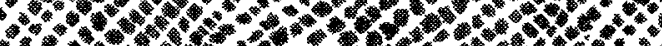

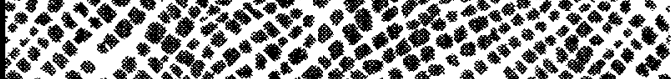

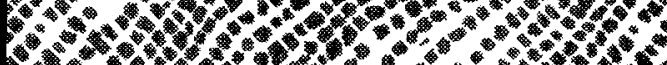

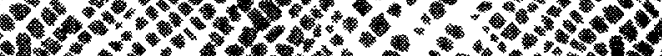
I.

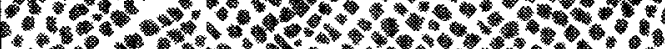

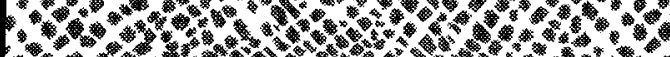

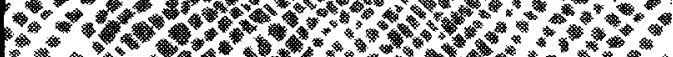

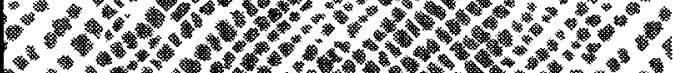

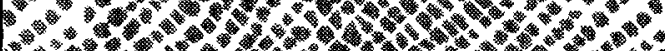

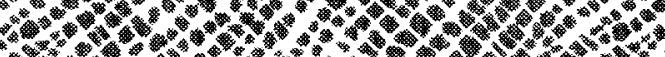

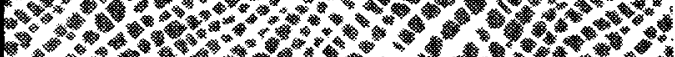

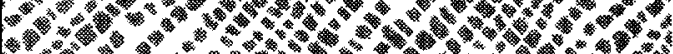

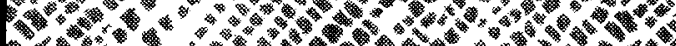

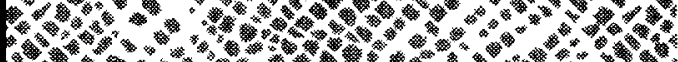

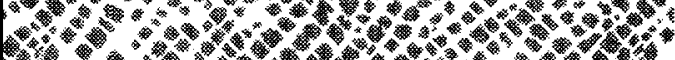

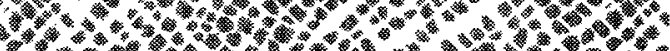

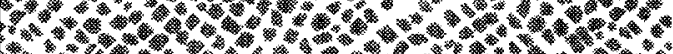

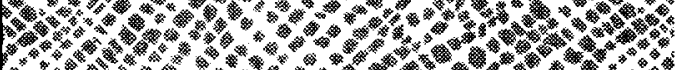

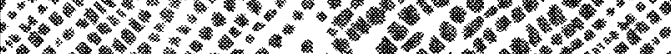

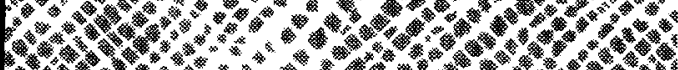

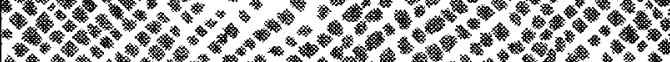

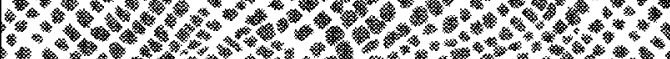

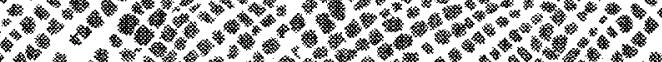

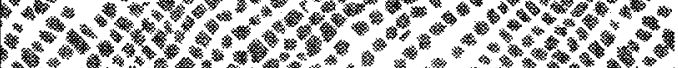

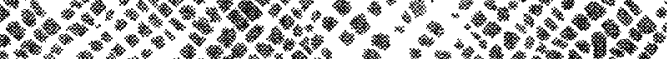

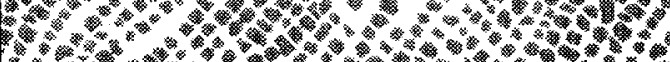

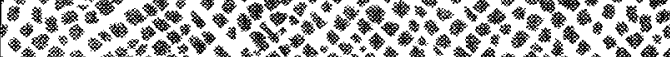

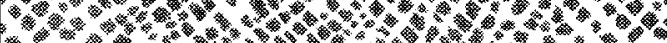

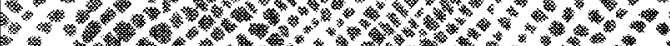

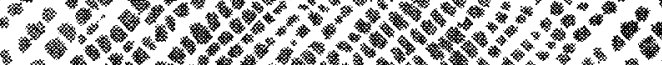

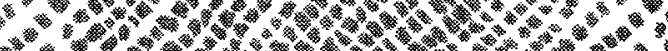

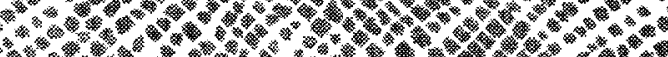

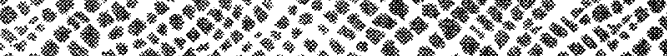

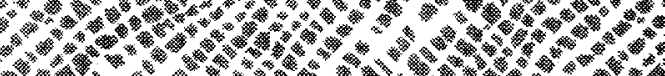

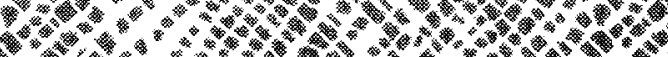

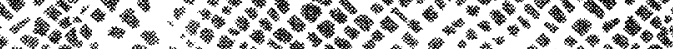

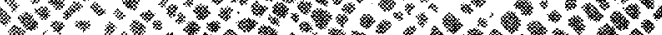

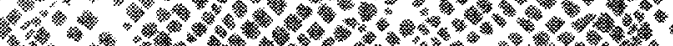
1.3.

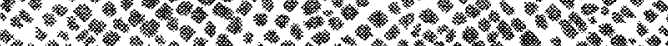

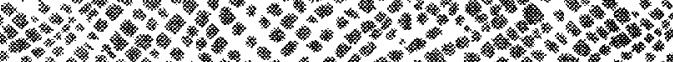

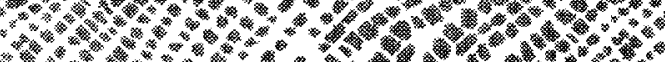

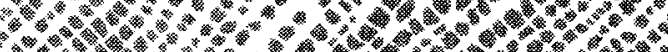
1.4.

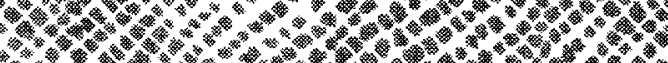

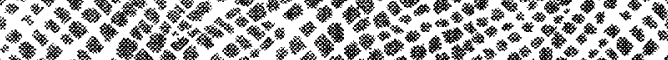

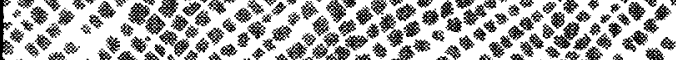

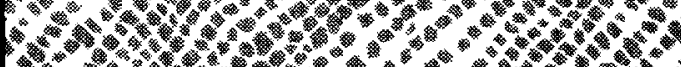

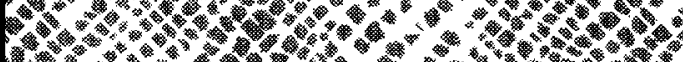

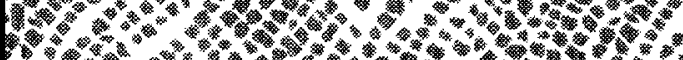

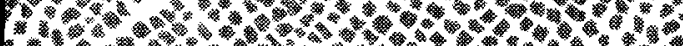

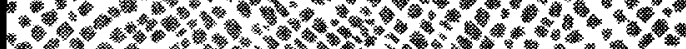

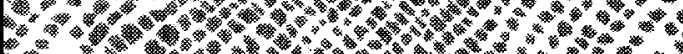

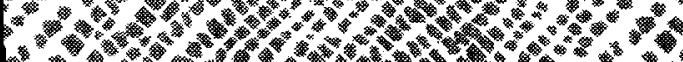

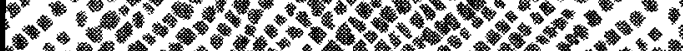

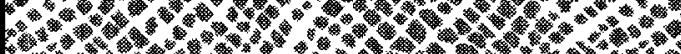

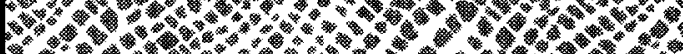

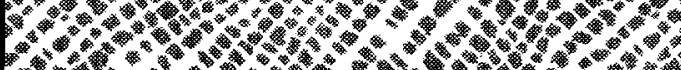

$$
\begin{aligned}
& \text { ECEIVEO } \\
& \text { OCT } 121999 \\
& \text { OSTI }
\end{aligned}
$$

\section{Site Scientific Mission Plan for the Southern Great Plains CART Site}

\author{
July-December 1997
}

Prepared for the U.S. Department of Energy under Contract W-31-109-Eng-38

Site Program Manager Office Environmental Research Division Argonne National Laboratory Argonne, IL 60439

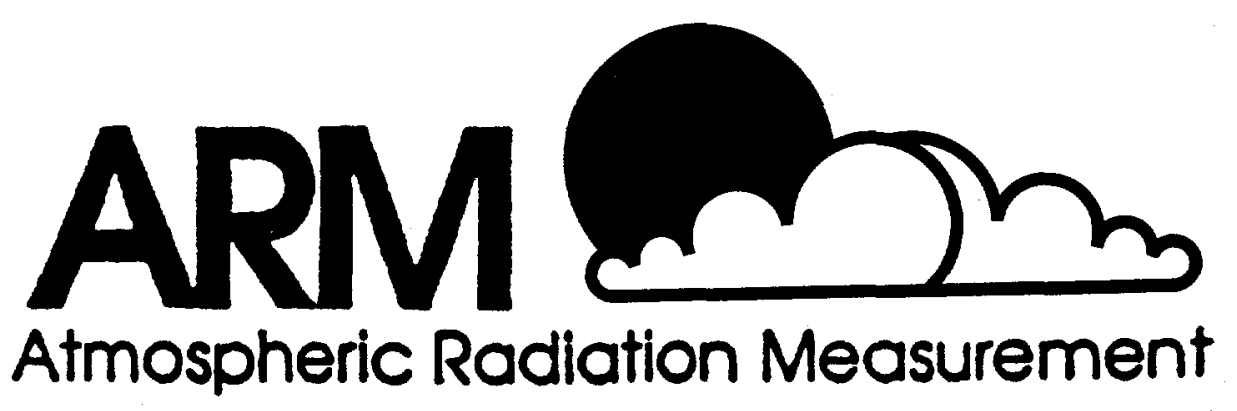




\section{DISCLAIMER}

This report was prepared as an account of work sponsored by an agency of the United States Government. Neither the United States Government nor an agency thereof, nor any of their employees, makes any warranty, express or implied, or assumes any legal liability or responsibility for the accuracy, completeness, or usefulness of any information, apparatus, product, or process disclosed, or represents that its use would not infringe privately owned rights. Reference herein to any specific commercial product, process, or service by trade name, trademark, manufacturer, or otherwise, does not necessarily constitute or imply its endorsement, recommendation, or favoring by the United States Government or any agency thereof. The views and opinions of authors expressed herein do not necessarily state or reflect those of the United States Government or any agency thereof.

Publishing support services were provided by Argonne's Information and Publishing Division. (For more information, see IPD's home page: http://www.ipd.anl.gov.)

Reproduced directly from the best available copy.

Available to DOE and DOE contractors from the Office of Scientific and Technical Information, P.O. Box 62, Oak Ridge, TN 37831; prices available from (423) $576-8401$.

Available to the public from the National Technical Information Service, U.S. Department of Commerce, 5285 Port Royal Road, Springfield, VA 22161. 


\section{DISCLAIMER}

Portions of this document may be illegible in electronic image products. Images are produced from the best available original document. 
Distribution Category:

Environmental Sciences (UC-402)

ARM-97-002

\section{Site Scientific Mission Plan for the Southern Great Plains CART Site July-December 1997}

July 1997

Randy A. Peppler ${ }^{1}$, Douglas L. Sisterson ${ }^{2}$, and Peter J. Lamb ${ }^{1}$

${ }^{1}$ Cooperative Institute for Mesoscale Meteorological Studies, The University of Oklahoma, Norman, Oklahoma 73019

2Environmental Research Division, Argonne National Laboratory, Argonne, Illinois 60439

Work supported by United States Department of Energy, Office of Energy Research, Office of Health and Environmental Research 


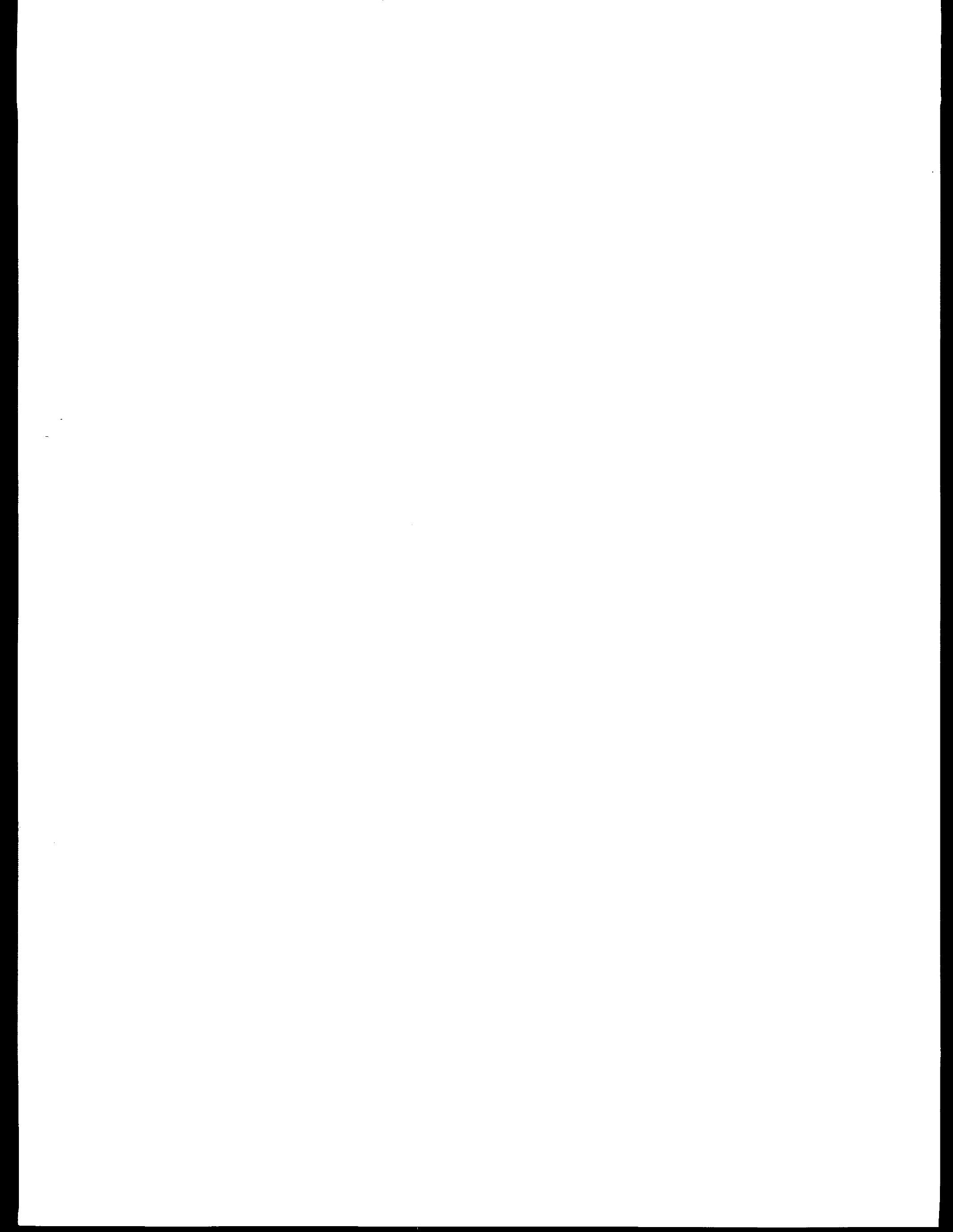




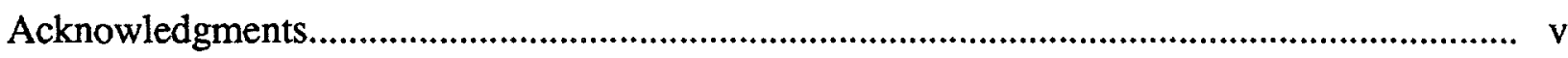

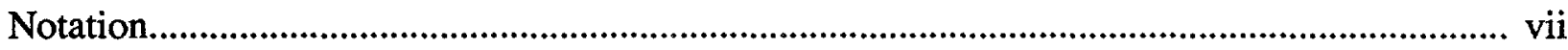

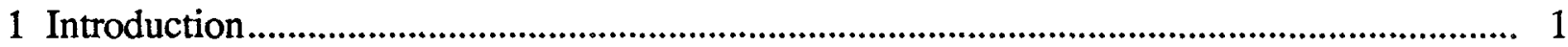

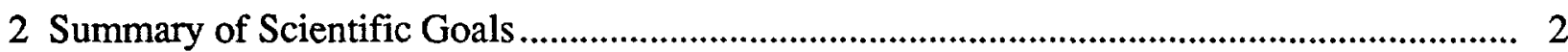

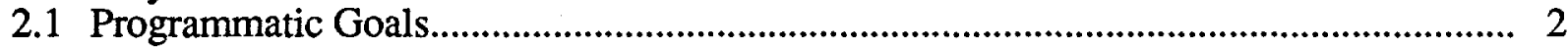

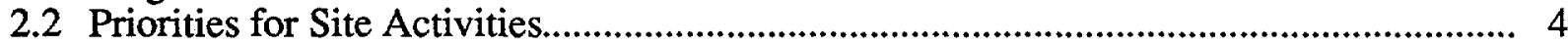

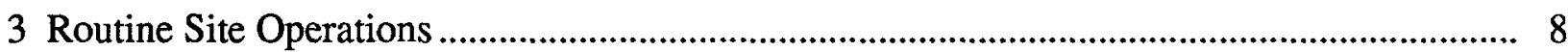

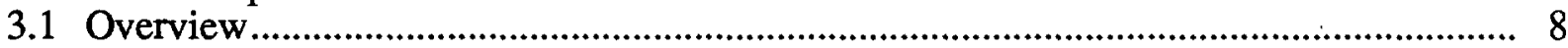

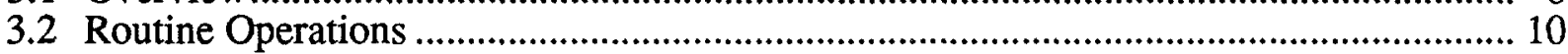

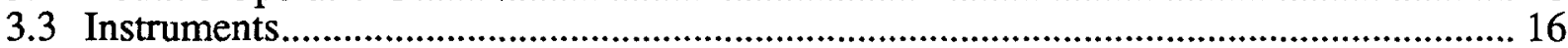

3.4 Observations, Measurements, and External Data ........................................................ 24

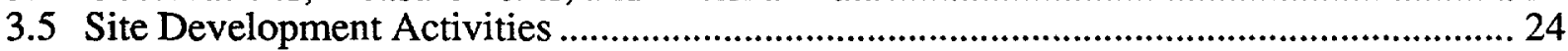

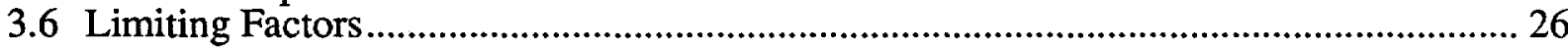

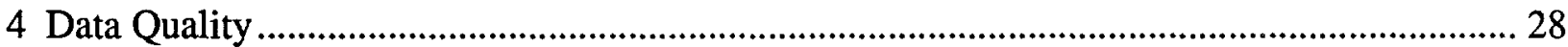

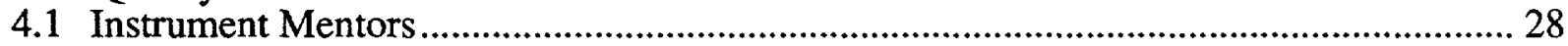

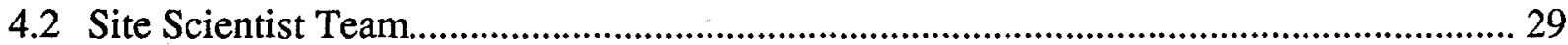

4.3 Value-Added Products and Quality Measurement Experiments ................................... 31

4.4 Problem Review Board ....................................................................................... 33

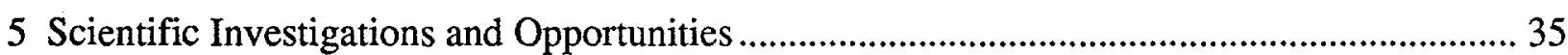

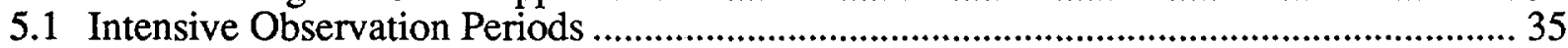

5.2 Intensive Observation Periods for this Six-Month Period ................................................ 38

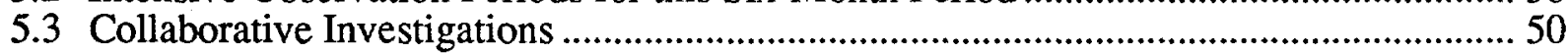

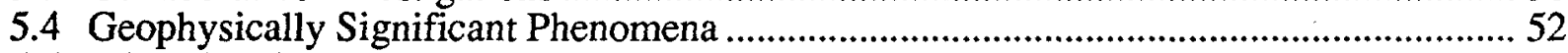

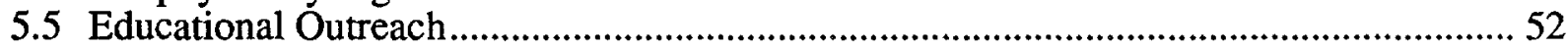

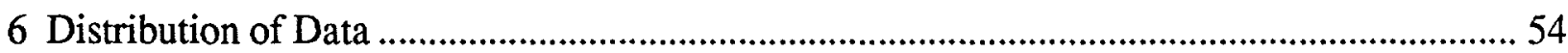

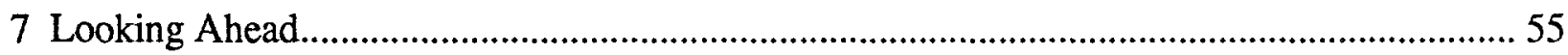

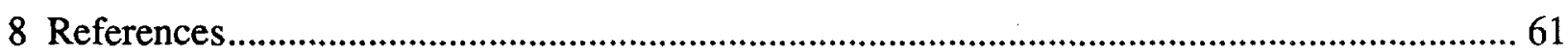

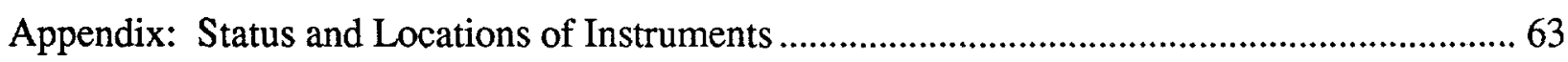

\section{FIGURES}

1 Overall View of the SGP CART Site........................................................................ 11

2 SGP CART Instrumentation Implementation Flowchart.................................................. 17 


\section{TABLES}

1 Instruments and Observational Systems Anticipated at the Central, Boundary, Extended, and Auxiliary Facilities on December 31, 1997

2 Radiosonde Launch Schedule for July 1-December 31, 1997 ............................................... 15

3 Value-Added Products in Place at the SGP CART Site ........................................................... 32

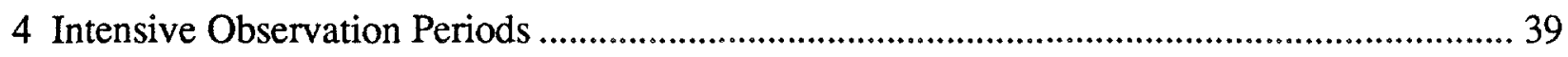

A.1 Actual and Planned Locations of Instruments at the Central Facility......................................6 65

A.2 Locations and Status of Extended Facilities .....................................................................6

A.3 Locations and Status of Intermediate Facilities ................................................................ 72

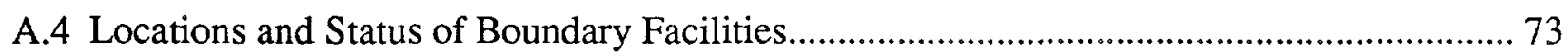




\section{ACKNOWLEDGMENTS}

This research was supported by the Atmospheric Radiation Measurement Program of the Environmental Sciences Division, Office of Health and Environmental Research, Office of Energy Research, U.S. Department of Energy, under contract PNL 144880-A-Q1 at the Cooperative Institute for Mesoscale Meteorological Studies, The University of Oklahoma (Peppler and Lamb), and under contract W-31-109-Eng-38 at Argonne National Laboratory (Sisterson).

The authors wish to thank the following for their much appreciated contributions to this report: Marvin Wesely, Argonne National Laboratory, for Section 3.3, Instruments; the VAP Working Group for Section 4.3, Value-Added Products and Quality Measurement Experiments, and Table 3; and Richard Cederwall, Lawrence Livermore National Laboratory, for Section 5.1 and Table 4, Intensive Observation Periods. 


\section{NOTATION}

ABLE

ABRFC

AERI

AMMR

ANL

AOS

ARESE

ARM

ASRC

ASTER

ASTI

AVHRR

AWS

BAMS

BBSS

BCR

BF

BFVceil

BLC

BLX

BORCAL

BRS

BSRN

CAR

CART

CASES

CASH

$\mathrm{CCN}$

CERES

CIMMS

CIMSS/SSEC

CIRA

CLASS

CLEX

CSPHOT

CSU

DIAL

DOE

DQR

DSIT

EBBR

ECMWF

ECOR
Argonne Boundary Layer Experiment

Arkansas Basin Red River Forecast Center

atmospherically emitted radiance interferometer

advanced multispectral microwave radar

Argonne National Laboratory

aerosol observation system

ARM Enhanced Shortwave Experiment

Atmospheric Radiation Measurement

Atmospheric Sciences Research Center

air-surface turbulence exchange research

absolute solar transmittance interferometer

advanced very-high-resolution radiometer

automated weather station

Bulletin of the American Meteorological Society

balloon-borne sounding system

baseline change request

boundary facility

boundary facility Vaisala ceilometer

Belfort laser ceilometer

Boundary Layer EXperiment

Broadband Outdoor Radiometer CALibration

broadband radiometer station

Baseline Surface Radiation Network

Corrective Action Report

Cloud and Radiation Testbed

Cooperative Atmosphere-Surface Exchange Study

commercial aviation sensing humidity

cloud condensation nuclei

Clouds and Earth's Radiant Energy System

Cooperative Institute for Mesoscale Meteorological Studies

Cooperative Institute for Meteorological Satellite Studies/Space Science

and Engineering Center

Cooperative Institute for Research in the Atmosphere

cross-chain loran atmospheric sounding system

Cloud Layer EXperiment

Cimel sunphotometer

Colorado State University

DIfferential Absorption Lidar

U.S. Department of Energy

Data Quality Report

Data and Science Integration Team

energy balance Bowen ratio

European Centre for Medium Range Weather Forecasts

eddy correlation 


\section{NOTATION (Cont.)}

$\begin{array}{ll}\text { EF } & \text { extended facility } \\ \text { EOP } & \text { Experimental Operations Plan } \\ \text { ETL } & \text { Environmental Technology Laboratory } \\ \text { FDDA } & \text { four-dimensional data assimilation } \\ \text { FSBR } & \text { fractional solar broadband radiometer } \\ \text { FTP } & \text { file transfer protocol } \\ \text { GCIP } & \text { GEWEX Continental-Scale International Project } \\ \text { GCM } & \text { general circulation model } \\ \text { GEWEX } & \text { Global Energy and Water Cycle Experiment } \\ \text { GFGR } & \text { Gagarin, Farruggia, Gibisch, Reis, Inc. } \\ \text { GIST } & \text { GEWEX Integrated System Test } \\ \text { GOES } & \text { geostationary orbiting Earth satellite } \\ \text { GPS } & \text { global positioning system } \\ \text { GRAMS } & \text { ground radiation measurement system } \\ \text { GSFC } & \text { Goddard Space Flight Center } \\ \text { GVFA } & \text { geophysical variable focus area } \\ \text { IDP } & \text { Instrument Development Program } \\ \text { IDPC } & \text { integrated data processing circuit } \\ \text { IF } & \text { intermediate facility } \\ \text { IOP } & \text { intensive observation period } \\ \text { IPM } & \text { instrument performance model } \\ \text { IR } & \text { infrared } \\ \text { IRF } & \text { instantaneous radiative flux } \\ \text { IRT } & \text { infrared thermometer } \\ \text { ISLSCP } & \text { International Satellite Land-Surface Climatology Project } \\ \text { ISM } & \text { Integrated Surface Mesonet } \\ \text { ISS } & \text { integrated sounding system } \\ \text { IT } & \text { Instrument Team } \\ \text { KSU } & \text { Kansas State University } \\ \text { LANL } & \text { Los Alamos National Laboratory } \\ \text { LBL } & \text { line by line } \\ \text { LBLRTM } & \text { line-by-line radiative transfer model } \\ \text { LLJ } & \text { Low-Level Jet } \\ \text { LMS } & \text { Lockheed Missile and Space } \\ \text { MAPS } & \text { Mesoscale Analysis and Prediction System } \\ \text { MFR } & \text { multifilter radiometer } \\ \text { MFRSR } & \text { multifilter rotating shadowband radiometer } \\ \text { MIR } & \text { microwave imaging radar } \\ \text { MMCR } & \text { millimeter cloud radar } \\ \text { MPL } & \text { micropulse lidar } \\ \text { MSU } & \text { Millersville State University } \\ \text { MSX } & \text { Midcourse Satellite Experiment } \\ \text { MWR } & \text { microwave radiometer } \\ \text { NASA } & \text { National Aeronautics and Space Administration } \\ & \end{array}$




\section{NOTATION (Cont.)}

NCAR

NCEP

NCSU

NEPA

NEXRAD

NFOV

NGM

NIP

NIST

NOAA

NREL

NSSL

NWS

OCS

OKM

ORR

OU

PAR

PARABOLA

PARC

PBL

PC

PI

PIF

PNNL

PRB

PROF

PRR

PSU

QME

RASS

RCF

RLID

RSS

RUC

RWP

SAC

SCM

SDS

SGP

SI

SIROS

SIRS
National Center for Atmospheric Research

National Centers for Environmental Prediction

North Carolina State University

National Environmental Policy Act

next-generation radar

narrow-field-of-view zenith-pointing filtered radiometer

nested grid model

normal-incidence pyrheliometer

National Institute of Standards and Technology

National Oceanic and Atmospheric Administration

National Renewable Energy Laboratory

National Severe Storms Laboratory

National Weather Service

Oklahoma Climatological Survey

Oklahoma Mesonet

Operational Readiness Review

University of Oklahoma

photosynthetically active radiometer

portable appartus for rapid acquisition of bidirectional observations

of the land and the atmosphere

Palo Alto Research Center

planetary boundary layer

personal computer

principal investigator

Problem Identification Form

Pacific Northwest National Laboratory

Problem Review Board

profile

Pre-Readiness Review

Pennsylvania State University

quality measurement experiment

radio acoustic sounding system

radiometer calibration facility

Raman lidar

rotating shadowband spectrometer

rapid update cycle

radar wind profiler

Site Advisory Committee

single-column model

site data system

Southern Great Plains

International System of Units

solar and infrared radiation observing system

solar and infrared station 


\section{NOTATION (Cont.)}

SITAC

SMOS

SNL

SORTI

SST

SUCCESS

SWATS

SWS

TBD

TDDR

TEMP

THWAPS

TLCV

T/RH

TSBR

TWP

UAV

UBC

UIR

UM

UNAVCO

UoM

URL

USDA

USR

UTC

UU

UV-A

UV-B

UW

VAP

Vceil

VORTEX

WPDN

WPL

WSI

WWW
Spectral Imagery Technology Applications Center

surface meteorological observation station

Sandia National Laboratories

solar radiance transmission interferometer

Site Scientist Team

Subsonic Aircraft: Contrail and Cloud Effects Special Study

soil water and temperature system

shortwave spectrometer

to be determined

total direct diffuse radiometer

temperature

temperature, humidity, wind, and pressure sensor

time-lapse cloud video

temperature and relative humidity sensor

total shortwave broadband radiometer

Tropical Western Pacific

unmanned aerospace vehicle

University of British Columbia

upwelling infrared radiometer

University of Massachusetts

University NAVSTAR Consortium

University of Maryland

universal resource locator

U.S. Department of Agriculture

upwelling solar radiometer

universal time coordinated

University of Utah

ultraviolet $A$

ultraviolet B

University of Wisconsin

value-added product

Vaisala ceilometer

Verification of the Origins of Rotation in Tornadoes Experiment

Wind Profiler Demonstration Network

Wave Propagation Laboratory

whole-sky imager

World Wide Web 


\section{SITE SCIENTIFIC MISSION PLAN \\ FOR THE SOUTHERN GREAT PLAINS CART SITE \\ JULY-DECEMBER 1997}

\section{INTRODUCTION}

The Southern Great Plains (SGP) Cloud and Radiation Testbed (CART) site is designed to help satisfy the data needs of the Atmospheric Radiation Measurement (ARM) Program Science Team. This document defines the scientific priorities for site activities during the six months beginning on July 1, 1997, and looks forward in lesser detail to subsequent six-month periods. The primary purpose of this Site Scientific Mission Plan is to provide guidance for the development of plans for site operations. It also provides information on current plans to the ARM functional teams (Management Team, Data and Science Integration Team [DSIT], Operations Team, Instrument Team [IT], and Campaign Team) and serves to disseminate the plans more generally within the ARM Program and among the members of the Science Team. This document includes a description of the operational status of the site and the primary site activities envisioned, together with information concerning approved and proposed intensive observation periods (IOPs). The primary users of this document are the site operator, the Site Scientist Team (SST), the Science Team through the ARM Program science director, the ARM Program Experiment Center, and the aforementioned ARM Program functional teams. This plan is a living document that is updated and reissued every six months as the observational facilities are developed, tested, and augmented and as priorities are adjusted in response to developments in scientific planning and understanding.

This report is available on the SGP CART site World Wide Web (WWW) home page at

http://www.arm.gov/docs/sites/sgp/sgp.html

under the heading "Site Scientific Mission Plan."

A distilled version of this document is currently being written for publication in the Bulletin of the American Meteorological Society and will be published either during this six-month period or in 1998. 


\section{SUMMARY OF SCIENTIFIC GOALS}

\subsection{Programmatic Goals}

The primary goal of the SGP CART site activities is to produce data adequate to support significant research addressing the objectives of the ARM Program. These overall objectives, as paraphrased from the ARM Program Plan, 1990 (U.S. Department of Energy 1990), are the following:

- To describe the radiative energy flux profile of the clear and cloudy atmosphere

- To understand the processes determining the flux profile

- To parameterize the processes determining the flux profile for incorporation into general circulation models (GCMs)

To address these scientific issues, an empirical data set must be developed that includes observations of the evolution of the radiative state of the column of air over the central facility, as well as the processes that control that radiative state, in sufficient detail and quality to support the investigations proposed by the ARM Science Team. To address the entire $350-\mathrm{km} \times 400-\mathrm{km}$ SGP CART site, the ARM Program relies on models to compute the processes or properties that affect radiative transfer. This set of data includes measurements of radiative fluxes (solar and infrared [IR]) and the advective and surface fluxes of moisture, heat, and momentum occurring within the column and across its boundaries. Other entities to be described are cloud types, composition, and distribution (depth, fractional coverage, and layering); thermodynamic properties of the columnar air mass (temperature, pressure, and concentrations of all three phases of water); the state and characteristics of the underlying surface (the lower boundary condition); processes within the column that create or modify all of these characteristics (including precipitation, evaporation, and the generation of condensation nuclei); and radiatively significant particles, aerosols, and gases. Basic continuous observations must be made as often as is feasible within budgetary constraints. For limited periods of time, these observations will be supplemented by focused IOPs providing higher-resolution or difficult-to-obtain in situ data.

Beyond simply providing the data streams, determining their character and quality as early as possible in the observational program is imperative. This evaluation will provide the 
basic operational understanding of the data necessary for an ongoing program of such scope. Although both reason and ample opportunity will exist to develop a further understanding of the ARM observations over the course of the program, the task of investigating and ensuring the data quality is extremely important. In this regard, routine instrument mentor and SST data quality assessments, definitive quality measurement experiments (QMEs), and value-added products (VAPs) will help establish confidence in the measurements.

The SGP CART site is the first of three global locations chosen and instrumented for data collection. As summarized in the Science Plan for the ARM Program (U.S. Department of Energy 1996), the scientific issues to be addressed by using data from a midlatitude continental CART observatory include the following:

- Radiative transfer in cloudless, partly cloudy, and overcast conditions

- Cloud formation, maintenance, and dissipation

- Nonradiative flux parameterizations

- The role of surface physical and vegetative properties in the column energy balance

- Other complications in the radiative balance in the atmosphere, particularly those due to aerosols, cloud condensation nuclei (CCN), and cloud-aerosol radiative interactions

- Feedback processes between different phenomena and different domains

The variety, surface density, and atmospheric volumetric coverage of the SGP instrumentation will be more comprehensive than those at any other ARM site, and the SGP site will experience a wider variety of atmospheric conditions than will any other ARM site. The resulting data will accordingly support a greater range and depth of scientific investigation than data from any other location, making it imperative for the ARM Program to develop and maintain a high-quality, continuous data stream from the SGP site.

The measurements required by Science Team proposals, the DSIT, and the science director are incorporated into geophysical variable focus areas (GVFAs). The DSIT and other 
teams coordinate activities to develop these integrated, well-focused data sets. The GVFAs include shortwave radiation, water vapor, longwave radiation, aerosols, clouds, surface fluxes, and the single-column model (SCM). A goal is to facilitate algorithm development that prescribes geophysical phenomena as products of multiple data streams rather than focusing on individual data streams.

\subsection{Priorities for Site Activities}

As the construction of the SGP CART site nears completion, the primary scientific goal has shifted from the establishment of routine observations to addressing the specific science issues related to the site. In descending order, we rank the priorities of site activities for July through December 1997 as follows:

1. Support all data quality assessment efforts, particularly those focused on shortwave radiation, including implementation of QMEs and VAPs.

2. Complete establishment and sustain high quality of routine site operations.

3. Plan and implement key IOPs and campaigns.

4. Finish implementation of extended facilities.

5. Support the Instrument Development Program (IDP).

Within this ranking, the differences in relative importance between adjacent items are not large. The categorization is also somewhat artificial because many site activities have multiple purposes. For example, IOP activities can simultaneously support Science Team, IDP, and campaign requirements. Even so, this ranking reflects our scientific assessment of the activities that should receive the most support during this period.

The IOPs focus on providing critical data sets on an episodic basis to the Science Team, as well as field support for instrument development and testing and for collaborative campaigns. The IOPs scheduled for this six-month period are detailed in Section 5.2.

To assist the SST with scientific issues, a Site Advisory Committee (SAC), consisting of seven scientists (approximately half from outside the ARM Program), provides scientific 
guidance for the SGP CART site. The SAC works directly with the SST and the site program manager. A report from a second SAC meeting held on June 11 and 12, 1996, in Norman, Oklahoma, became available in April 1997. That meeting followed up on the first SAC meeting (November 27-29, 1995), which included a visit to the SGP CART site. Another meeting is scheduled for late 1997.

Routine radiosonde observations will continue to include five daily balloon-borne sounding system (BBSS) launches on Monday through Friday (including holidays) at the central facility. One routine daily launch will continue on Monday through Friday (including holidays) at each of the four boundary facilities. Three SCM IOPs, each lasting for three weeks, are now conducted each year. Spring and summer SCM IOPs are scheduled annually, while fall and winter SCM IOPs alternate between years. Single-column model IOPs are scheduled for June-July and September-October 1997. Other IOPs will be going on during these two SCM periods, including the U.S. Department of Agriculture (USDA)/National Aeronautics and Space Administration (NASA) SGP '97 (Hydrology) IOP in the summer and the ARM Fall 1997 Integrated IOP. See Sections 5.1 and 5.2 and Table 4 for more details.

During the last six-month period of 1996 , the $915-\mathrm{MHz}$ profilers with radio acoustic sounding systems (RASSs) were successfully deployed at locations between the central and boundary facilities; these locations are known as intermediate facilities. These profilers will enhance the boundary layer monitoring across the SGP CART site.

A unique opportunity to supplement the existing CART instrumentation was proposed by the SST and has been funded by the Global Energy and Water Cycle Experiment (GEWEX) Continental-Scale International Project (GCIP), housed within the National Oceanic and Atmospheric Administration (NOAA) Office of Global Programs. This support has permitted sensors for the profiling of soil water and temperature systems (SWATSs) to be installed at the central facility and the extended facilities during the last six-month period, with the network essentially completed in the spring of 1997 . These additional sensors will support water and energy budget analyses, diagnostic studies, and model validation efforts of ARM and GCIP investigators.

Operation of the radiometer calibration facility (RCF) has started, with personnel from the National Renewable Energy Laboratory (NREL) currently performing most of the work, assisted by site operations personnel. Although plans for overall operation of this facility are being formulated, successful calibration was first carried out in September 1996. Routine 
operations of the RCF are expected to be implemented during this period, with another calibration beginning in June 1997.

The emphasis on deployment in this six-month period will be on the split of the solar and infrared radiation observing system (SIROS) into a solar and infrared station (SIRS) and a multifilter rotating shadowband radiometer (MFRSR) at each of the extended facilities and on the new radiometers at the central facility. The number of radiometers to be installed at the central facility led to an expansion of the central cluster and a new area called the optical trailer cluster, which is located south of the optical trailer and north of the central cluster. Priority instruments to be installed during this time period include the time-lapse cloud video (TLCV), the rotating shadowband spectrometer (RSS), and the ground radiation measurement system (GRAMS) in the optical trailer cluster, and the Cimel sunphotometer (CSPHOT) in the expanded southern area of the central cluster. All but the SIROS split will be completed before the Fall 1997 Integrated IOP.

The phased implementation of the Okmulgee extended facility (the wooded site) has begun. The walk-up tower, shelter, and infrastructure are expected to be in place during this period. In addition, a Memorandum of Understanding with the USDA in support of GEWEX studies will allow the costs of installation to be shared with ARM for phased implementation and completion of a fully instrumented extended facility at El Reno during this six-month period. This energy balance Bowen ratio (EBBR) site will be used in support of the GEWEX studies. A solar-powered EBBR and SWATS with cellular phone data communications have been installed temporarily in support of the Hydrology IOP.

The IDP millimeter cloud radar (MMCR) is expected to become a CART instrument during this six-month period. It was successfully tested during a validation IOP during the period of April 2-22, 1997. In addition, four Vaisala 25-km ceilometers and four atmospherically emitted radiance interferometers (AERIs) are expected to be installed at boundary facilities this fall. A single AERI, the first of four, will be installed at the Purcell boundary facility. The disposition of the eddy correlation (ECOR)-based Ft. Cobb is yet to be determined. Establishment of one auxiliary facility will be needed to accommodate the installation of a second day-night whole-sky imager (WSI).

In addition, one office trailer is expected to be added to the compound area of the central facility, and a phased implementation of IDP No. 4 and storage area will begin at the area 
formerly occupied by the abandoned farmhouse at the extreme southeast corner of the central facility. This area is expected to be minimally operational by the Fall 1997 Integrated IOP.

Finally, a master's-degree-level on-site scientist will be hired and will reside full time at the central facility during this period. The primary function of this position is to support the SST data-quality-modules development activities and also to provide assistance to site operations functions that may improve the overall quality of the data streams generated at the SGP CART site.

In summary, our goals for this six-month period continue to be to provide the Science Team with a suite of measurements that will support a wide range of research, to establish solid procedures for instrument calibration and maintenance (particularly for broadband radiometry), to operate the series of QMEs, to provide input for the GVFAs, and to install required instrumentation and facility support. Quality assessment efforts are central to the success of the entire program. Section 4 further describes this emphasis. 


\section{ROUTINE SITE OPERATIONS}

\subsection{Overview}

The overwhelming majority of the measurements with the highest priority, on which the existing experimental designs are based, are regular (i.e., routine) observations, as specified in the ARM Program Plan, 1990 (U.S. Department of Energy 1990). Scientifically and logistically, routine operations will also serve as the basis and background for all nonroutine operations, including instrument development activities, IOPs, and collaborative campaigns directed toward obtaining difficult-to-gather or expensive in situ data. Consequently, development and validation of the basic observations remain high priorities. Site development has progressed sufficiently to support IOPs addressing key scientific questions. The IOPs are an opportunity to provide more focused data sets to the Science Team and the scientific community at large.

The SST will continue to work to ensure the scientific productivity of the site by providing guidance to the site operations manager and his staff on scientific matters related to instrument performance via the quality of the data stream, by answering questions from operations personnel concerning potential instrument problems, by reviewing schedules and procedures for instrument maintenance and calibration, by reviewing designs for infrastructure supporting new instruments, by contributing to the design of the standard operating procedures, by reviewing and developing plans for IOPs, and by helping to obtain near-real-time data displays for IOPs. The SST, in cooperation with instrument mentors and the DSIT, will continue to lead the data quality assessment effort at the CART site, an ongoing activity that includes monitoring of the CART data streams in collaboration with the staff at the central facility and the development of data quality performance metrics and graphical tools that will address the data originating at the SGP site. A special focus during this six-month period will continue to be on shortwave radiation data or anticipation of the Clouds and Earth's Radiant Energy System (CERES) launch in August 1997. These activities are discussed in more detail in Section 4 of this report.

Routine operations are considered to be the activities related to the operation and maintenance of instruments, the gathering and delivery of the resulting data, and the planning for scientific investigations, including IOPs, campaigns, and QMEs. Although the site is essentially complete, instrumentation will be evaluated continuously to assess the need for possible elimination of instruments or replacement with updated or new sensors. The process that leads 
to implementation of CART instruments continues to be the Pre-Readiness Review (PRR). The PRR includes the identification of requirements for instrument design and installation and the development of the documentation, procedures, and training needed to maintain CART instrumentation and integrate data streams into the site data system (SDS). The PRR also provides a forecast of when these instruments will be fully operational (i.e., operational handoff to site operations via the Operational Readiness Review [ORR]) and delivering data to the Experiment Center and the Archive.

The design expectation for the routine operation of instruments is that they will require servicing by site operators only once every two weeks. The exception to this is the central facility and the boundary facilities, which are staffed. If an instrument fails during a two-week period at an extended facility, data streams could be lost, although every effort is made to ensure adequate data-logging capacity at each remote site. Such loss of data is unfortunate but deemed acceptable to the ARM Program because of manpower and budget constraints. The data collected at all extended and boundary facilities by the end of this period are expected to be polled frequently each day by the SDS at the central facility and then packaged and delivered to the Experiment Center and the Archive once daily. The Experiment Center generally delivers data to Science Team members and other data requesters once weekly via an Experimental Operations Plan (EOP).

Site operations staff conduct instrument triage during IOPs and campaigns. The triage plan calls for IOP scientists to identify instruments, individual sensors, and communication links that are critical to the operation and goals of the IOP so that these instruments will receive more frequent servicing than that prescribed by routine operational requirements mentioned above. The priority of triage efforts is determined by the SST and IOP scientists and the site program manager, who take into consideration the scientific importance of a particular data stream and its expense. The triage plan has been very successful, as demonstrated during the recent IOPs for the ARM Enhanced Shortwave Experiment (ARESE), for the Subsonic Aircraft: Contrail and Cloud Effects Special Study (SUCCESS), and for the first Water Vapor IOP. The triage plan will continue to be an ongoing effort during IOPs in the upcoming six months.

Handling of instruments that must be returned to the vendor for calibration and servicing is also part of routine operation. Replacement instruments and sensors will be rotated regularly to meet these requirements. Calibration and maintenance information is being compiled by the SST in conjunction with the site program manager, site operations manager, and instrument mentors in order both to properly operate and maintain site instruments and to provide pertinent 
information to data users. Changeouts of all sensors and instrumentation are recorded in the site operations log.

The initial checks on data quality after instrument installation are provided by the instrument mentors. After the mentor reviews the data stream to ensure that the acquired instrument is performing properly and that the data are identified accurately by the Experiment Center, the mentor approves a "beta" release of the data. The beta release provides data to selected Science Team members who have requested them and are willing to work with the instrument mentor on data quality issues. Beta releases are established after the instrument mentor and an appropriate member of the DSIT create a general statement on data quality for the Experiment Center. Beta releases are also available to other Science Team members who are willing to work in conjunction with the instrument mentor. When the data quality relative to proper instrument functionality is consistently acceptable and well documented, the mentor approves a full release of the data.

\subsection{Routine Operations}

\subsubsection{Functional Instruments and Observational Systems}

Figure 1 is a map of the SGP site showing the locations of the developed extended, intermediate, and boundary facilities. The status of the systems and instruments anticipated by December 31,1997 , is summarized in Table 1.

Accomplishments in the area of site development are most evident at the central facility (Table A.1 in the Appendix), with its functioning power, fiber-optic infrastructure, and nearcomplete array of instruments. Of the 26 planned extended facilities (Table A.2 in the Appendix), 22 (including one at the central facility and one at the Cement location) are operational at the beginning of this period, two (Okmulgee, the wooded site; and El Reno) are expected to be operational by the end of this six-month period, one (Ft. Cobb) is yet to be identified, and one is a placeholder site for possible expansion, if required.

In addition, ARM is developing a mission critical database (metadata) that will make it possible to provide a common location for all information (other than instrument data streams) that enhances the scientific utility of the individual instrument data streams. Any information 


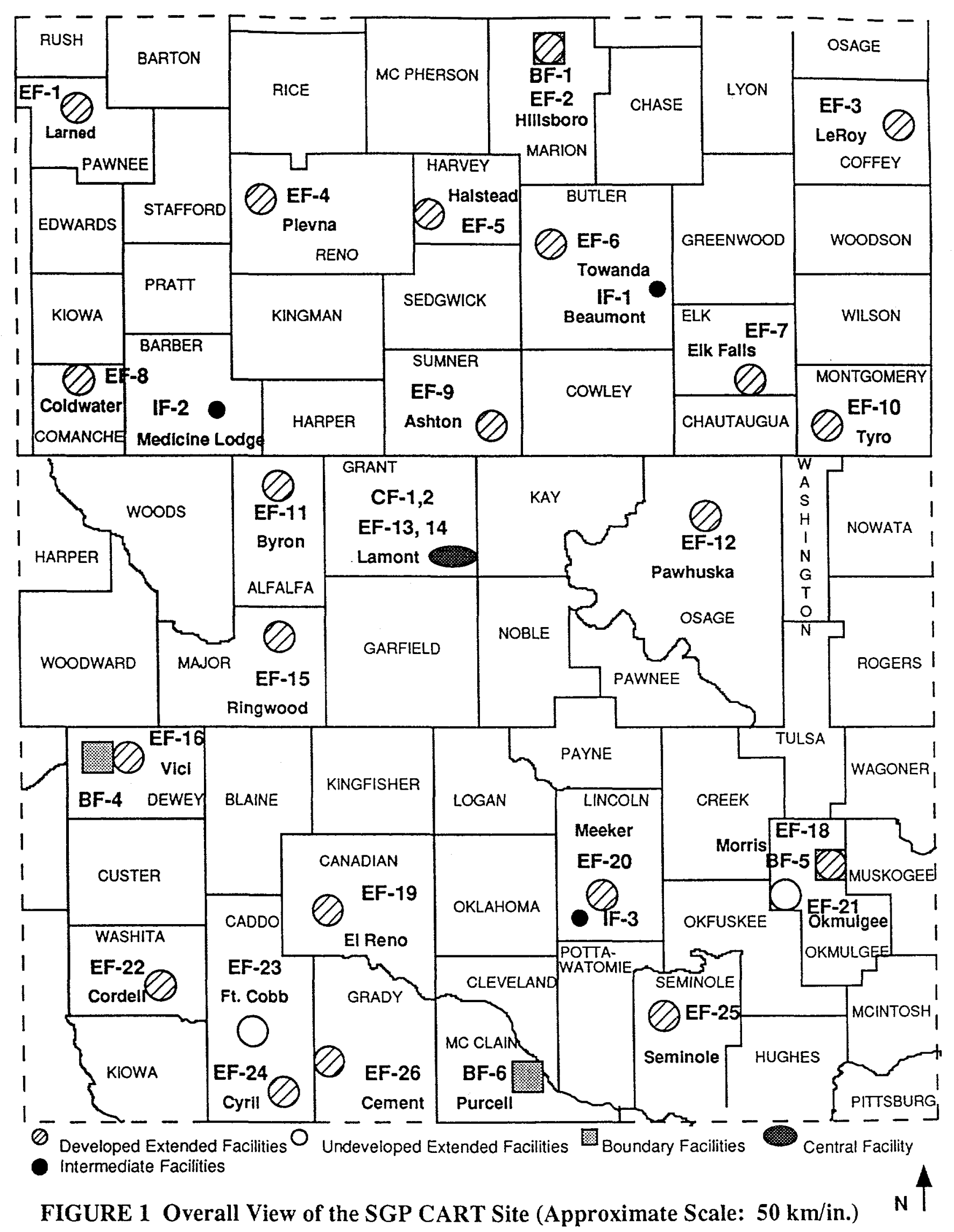


TABLE 1 Instruments and Observational Systems Anticipated at the Central, Boundary, Extended, and Auxiliary Facilities

on December 31, 1997a

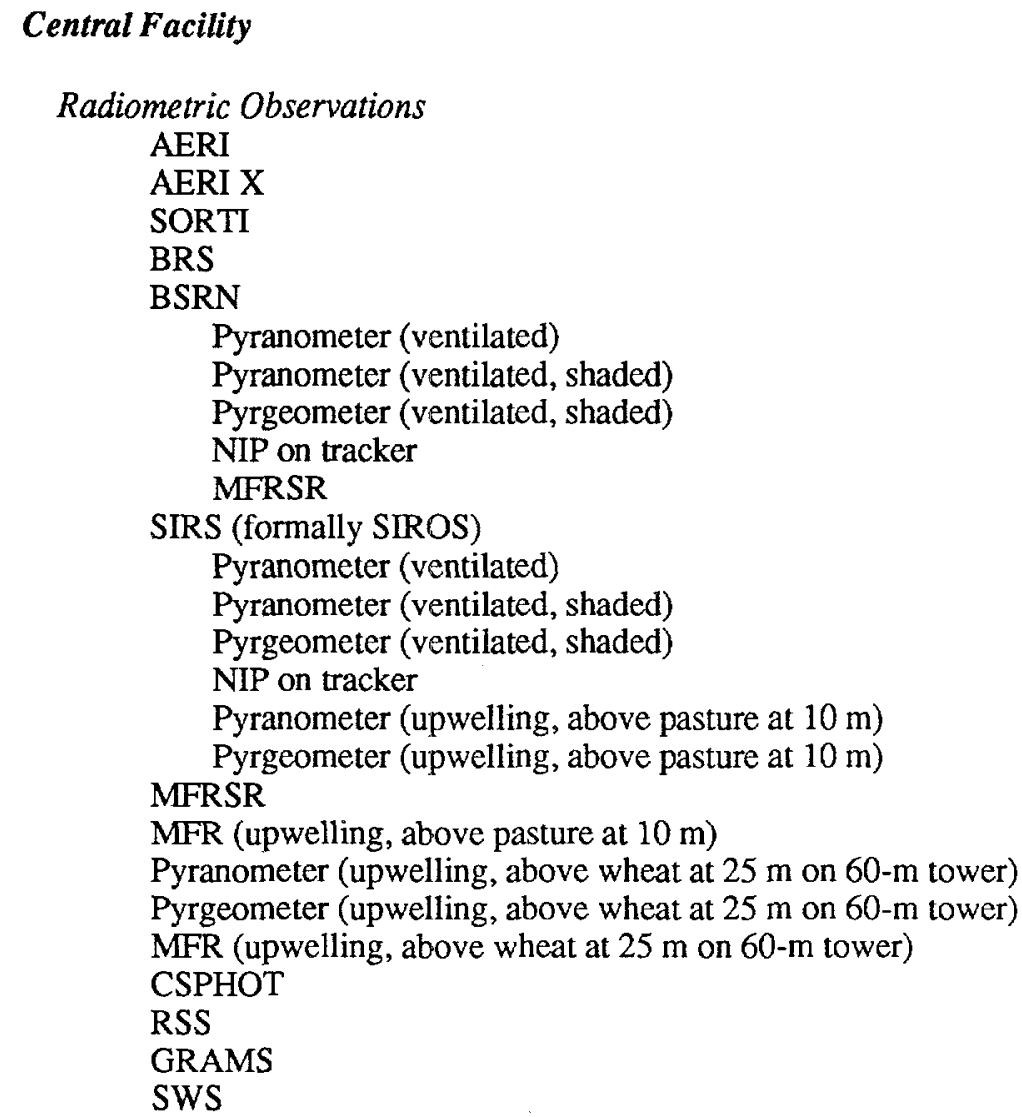

Wind, Temperature, and Humidity Sounding Systems

BBSS

915-MHz profiler with RASS

$50-\mathrm{MHz}$ profiler with RASS

MWR

Heimann IR thermometer

Raman lidar

Cloud Observations

WSI (daytime/nighttime)

BLC (interim)

MPL (IDP) ceilometer

MMCR

Vceil

TLCV 
TABLE 1 (Cont.)

Others

Temperature and humidity probes at $25-\mathrm{m}$ and $60-\mathrm{m}$ levels on tower Heat, moisture, and momentum flux at $25-\mathrm{m}$ and $60-\mathrm{m}$ levels on tower EBBR

ECOR

SMOS

AOS (samples at $10 \mathrm{~m}$ )

$\mathrm{RCF}$

\section{Extended Facility Components}

SIROS

Pyranometer (ventilated)

Pyranometer (ventilated, shaded)

Pyrgeometer (ventilated, shaded)

NIP on tracker

MFRSR

Pyranometer (upwelling, at $10 \mathrm{~m}$ )

Pyrgeometer (upwelling, at $10 \mathrm{~m}$ )

EBBR or ECOR

SMOS

SWATS

\section{Auxiliary Facilities}

None in preparation

Boundary Facilities

BBSS

MWR

BFVceil

\section{Intermediate Facilities}

915-MHz profiler and RASS

a AERI, atmospherically emitted radiance interferometer; AOS, aerosol observation system; BBSS, balloon-borne sounding system; BFVceil, boundary facility Vaisala ceilometer; BLC, Belfort laser ceilometer; BRS, broadband radiometer station; BSRN, Baseline Surface Radiation Network; CSPHOT, Cimel sunphotometer; EBBR, energy balance Bowen ratio; ECOR, eddy correlation; GRAMS, ground radiation measurement system; IDP, Instrument Development Program; IR, infrared; MFR, multifilter radiometer; MFRSR, multifilter rotating shadowband radiometer; MMCR, millimeter cloud radar; MPL, micropulse lidar; MWR, microwave radiometer; NIP, normal-incidence pyrheliometer; RASS, radio acoustic sounding system; RCF, radiometer calibration facility; RSS, rotating shadowband spectrometer; SIROS, solar and infrared radiation observing system; SIRS, solar and infrared station; SMOS, surface meteorological observation station; SORTI, solar radiance transmission interferometer; SWATS, soil water and temperature system; SWS, shortwave spectrometer; TLCV, time-lapse cloud video; Vceil, Vaisala ceilometer; WSI, whole-sky imager. 
that improves the scientific utility of the data is available at the ARM metadata WWW site:

http://www.db.arm.gov/ARM/MDS/mds.html .

Currently, such information only includes the site operation logs and maintenance records. Considerable interaction will take place within the ARM infrastructure during this six-month period to integrate other ARM Program databases.

\subsubsection{Launch Schedule for Balloon-Borne Sounding Systems}

Until the full suite of remote sensing systems is deployed to perform deep, detailed soundings of the wind, temperature, and moisture of the troposphere under a wide range of conditions, the BBSS will continue to be an expensive workhorse owing to the cost of the expendables and manpower associated with an ambitious schedule of radiosonde launches. The number of BBSS launches sitewide may eventually be reduced to a minimum needed to support routine cross-checks on the remotely sensed measurements. The frequency of routine launches at the central facility during this six-month period will be the same as in the previous six months. Routine operations (see Table 2) will include five daily launches at the central facility and one daily launch at each of the four boundary facilities.

The current routine radiosonde launch times at the central facility were chosen to facilitate instantaneous radiative flux (IRF) and IDP research, and the launch times at the boundary facilities were chosen to support the microwave radiometer (MWR) and the nearby NOAA 404-MHz profilers with their recent or imminent RASS deployment and to complement the wider network of National Weather Service (NWS) radiosonde launches. Remote sensing of virtual temperature profiles at all boundary facilities is provided by the nearby NOAA profilers, which are being outfitted with ARM-provided RASS units. The RASS units have already been installed at the Purcell, Oklahoma, and at the Haviland, Kansas, NOAA profilers. The Lamont, Oklahoma, NOAA profiler will not receive a RASS unit because it would be located too close to a residence, but the nearby SGP CART site central facility collects a relative abundance of thermodynamic data. In addition, global positioning system (GPS) instruments were recently installed at the Purcell, Vici, Morris, and Hillsboro NOAA profiler locations to provide estimates of precipitable water. This information is expected to become available to the ARM Program during this period as external data, along with the NOAA profiler data. 
TABLE 2 Radiosonde Launch Schedule for July 1-December 31, 1997 (Times in UTC) $^{\text {a }}$

Central Facility Boundary Facilities

SCM and Hydrology IOP Operations, July 1-July 18; and the Fall 1997 Integrated IOP Operations, September 15-October 3, Monday-Sunday

$\begin{array}{ll}0300 & 0300 \\ 0600 & 0600 \\ 0900 & 0900 \\ 1200 & 1200 \\ 1500 & 1500 \\ 1800 & 1800 \\ 2100 & 2100 \\ 2400 & 2400\end{array}$

Routine Operations, July 19-September 14 and October 4December 31, Monday-Friday

0600

1200

1500

1800

1800

2100

a IOP, intensive observation period; SCM, single-column model; UTC, universal time coordinated. Launch time is $30 \mathrm{~min}$ earlier; the stated time represents the approximate midpoint of the flight.

The four boundary facilities routinely launch radiosondes once daily at 1800 universal time coordinated or noon local time. Boundary facilities will continue to be staffed only during the period of 1030-1430 local time, Monday through Friday (including holidays). During appropriate IOPs, the boundary facilities will be staffed 24 hours per day for 21 consecutive days (including holidays) to facilitate releases every 3 hours (Table 2).

The central facility will be staffed from 0430 to 1630 and from 2230 to 0230 local time, Monday through Friday (including holidays). During SCM IOPs, the central facility will be staffed 24 hours per day, 7 days per week (including holidays), to facilitate round-the-clock radiosonde releases every 3 hours. Hours vary for other IOPs or campaigns, depending on the operational requirements for the central facility. 


\subsection{Instruments}

A CART instrument is any instrument that is approved by the ARM Program and for which the site operations management has accepted responsibility for operation and maintenance. The PRR and ORR forms are requests for information that facilitates the installation and operation of instruments or facilities at the SGP CART site. The purpose of these reviews is to achieve an efficient handoff of instruments and facilities from instrument mentors to site operators. Figure 2, the SGP CART instrumentation implementation flowchart, contains information obtained from the PRR and ORR documentation. When all procedures, operation manuals, and training pertaining to an instrument have been completed, the instrument is accepted by the site operations management. If sufficient documentation is available to operate an instrument, even though more will ultimately be required for full acceptance, the instrument may be operated in a degraded mode.

Once site operations personnel have accepted instruments, their design and configuration are "locked in" by using a configuration management system that is controlled by site operations. Any modifications to instruments or data systems require a baseline change request (BCR). The $\mathrm{BCR}$ process has been upgraded to a secure Web-based system. A request for a change is an E-mail narrative of the issues and potential impact. Such requests usually come from the instrument mentors. The site program manager is the control for the BCR process and assigns infrastructure for review and approval. Those participating in the review and approval process are provided with passwords to gain access to the BCR database.

Instruments recently installed or expected to be installed include the following:

- Millimeter Cloud Radar, Installed. Installation of an MMCR was completed in December 1996 and passed on-site tests. During April 1997, a Cloud Radar IOP was held. Development of ingest routines is a high priority, and considerable documentation has been developed and received by site operations for review.

- Soil Water and Temperature Systems for Measuring Vertical Profiles of Soil Water Content and Temperature (a Joint Venture between GCIP and ARM), Installed at Existing Extended Facilities. Data ingest and delivery to the Experiment Center are expected to be completed during this summer. 


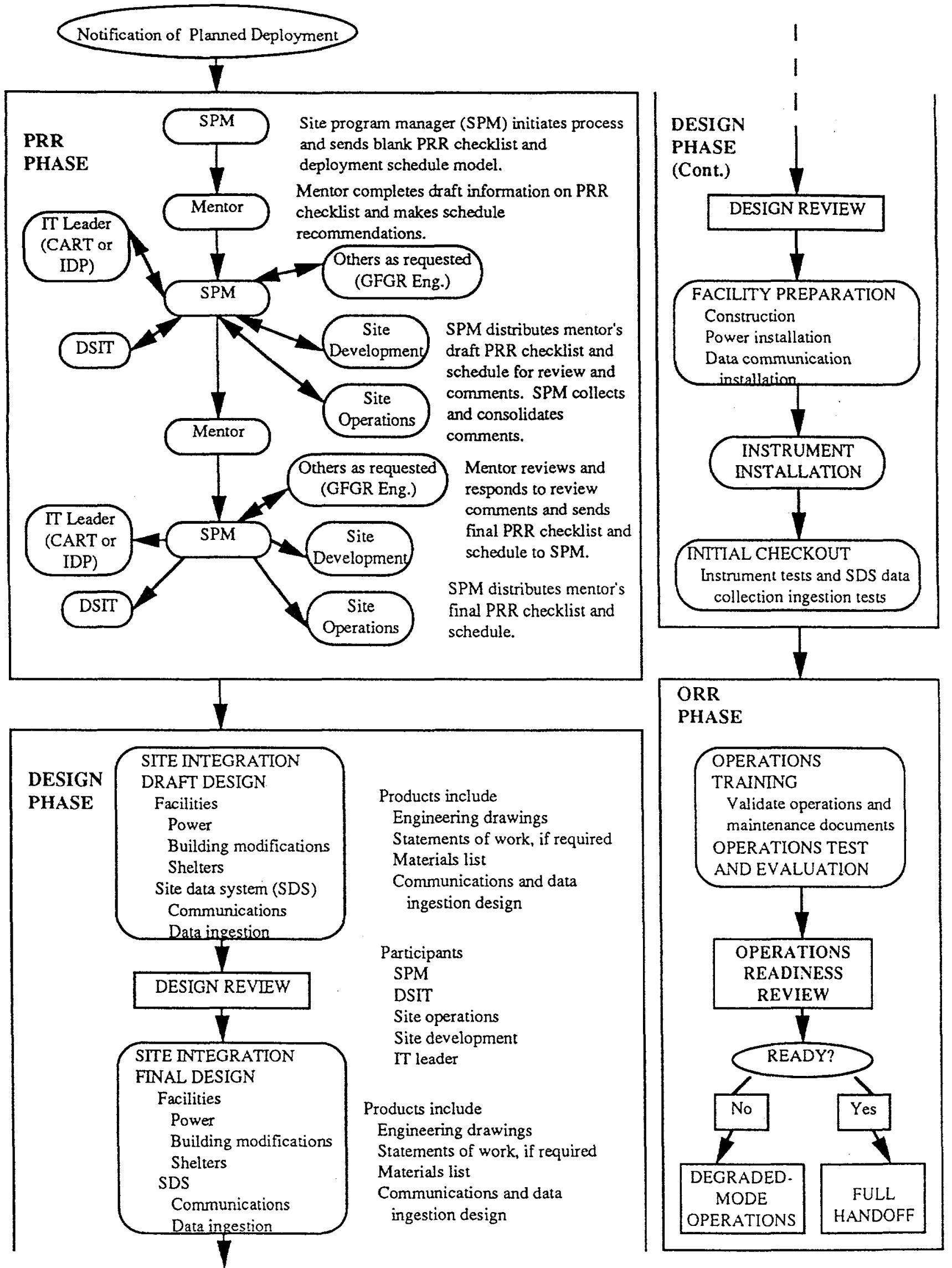


- Extra High-Resolution AERI X, Installed. A need was stated during early phases of CART planning to have at least two IR interferometers running routinely at the central facility. Two systems were said to be needed to improve evaluation of the uncertainties of the radiance observations. Because the AERI $X$ has a resolution about 10 times greater than the AERI and would provide the best available emission observations for comparison with line-by-line calculations, it could be considered an enhancement or new observation, in addition to contributing to completion of the site instrumentation. The high-resolution system provides a more independent check of radiance readings than would a second AERI of standard resolution because a different type of interferometer is used. A prototype AERI X has run successfully at the central facility on several occasions. Acquisition of an AERI $X$ for routine operation at the central facility became a reality in early 1997, and data monitoring continues.

- Addition of Rain Gauges at Six SWATS Locations Where No Surface Meteorological Observation Station Exists, Installed. These rain gauges are needed in proximity to SWATS to learn more about the flux of water from the near-surface atmosphere through the layers of soil measured by SWATS for realistic soil water balance estimations. The data are necessary for determining soil moisture characteristics for distributed surface models and for building empirical relationships between soil water status and surface energy and water partitions. Studies have shown that antecedent precipitation is a dominant cause of spatial variation in surface exchanges across a wide area like the CART site, working its way through into a convective response in the atmosphere, perhaps influencing cloud formation. This work was completed in early 1997.

- Temperature and Humidity Observations on the 60-m Tower, Installed. An additional level of temperature and humidity observations was added at the 25-m level of the 60-m tower at the central facility. As a result of the Water Vapor IOP in September 1996, improvements in selection, handling, and calibration of sensor elements have been implemented. Additional temperature and humidity sensors for both the $25-\mathrm{m}$ and $60-\mathrm{m}$ levels have been installed. 
- Improved Solar and Infrared Radiation Observing System Data Logging at Extended Facilities, in Progress. New data loggers and associated data equipment have been acquired to provide an independent data logger for the non-MFRSR components of SIROSs and for the central facility Baseline Surface Radiation Network (BSRN). The new platforms will be named SIRS and broadband radiometer station (BRS) for "solar and infrared station" and "broadband radiometer station," and the MFRSRs will have independent "MFRSR" platform names. A schedule for implementation calls for conversion to be completed by August 1997, but this scheduled date will likely be pushed back until later in 1997. The new SIRS platform is expected to have considerably greater reliability than that achieved with the MFRSRlogger-based platform, and the computations will allow data capture that meets international standards.

- Radiometer Calibration Facility, Installed. During the first six-month period of 1996, the construction of the RCF was completed. Fully operational, the facility includes a calibration deck; a site reference cavity radiometer; a program reference cavity radiometer; a site working-standard cavity radiometer; automatic solar trackers for direct and diffuse solar measurements; reference diffuse pyranometers; working-standard pyranometers, pyrheliometers, and pyrgeometers; and computer hardware and software support. The RCF will greatly aid the ARM Program in its ability to collect the best radiometric data possible. The first Broadband Outdoor Radiometer CALibration (BORCAL) was held successfully at the RCF in September 1996, and the second will take place in July 1997.

- Time-Lapse Cloud Video, in Progress. Implementation of a video camera and reflector to obtain time-lapse video views of cloud conditions above the central facility is taking place. The instrument for this TLCV is expected to be installed in the optical trailer cluster and become operational this summer.

- Cimel Sunphotometer at the Central Facility, in Progress. A CSPHOT is being acquired for installation at the central facility. The CSPHOT will provide measurements of aerosol optical depth to supplement the MFRSR and to tie in with a global network of each sunphotometer supported in part by NASA. In addition to measuring optical depths, the system will be used to 
observe the sky radiance along the solar almucantar and along the solar principal plane, including the solar aureole. The resulting data can be used for research on inferring aerosol size distribution and the scattering phase function. This instrument is expected to be installed in the expanded central cluster and become operational this summer.

- The UV-B and Photosynthetically Active Radiation Sensors, in Progress. A set of sensors and a data logger have been acquired to measure the downwelling hemispheric solar radiation in the ultraviolet B (UV-B) and photosynthetically active radiometer (PAR) bands at the central facility. Making these observations is an efficient means of increasing collaborations with other programs. Implementation has been delayed because of the potential need to include additional relatively simple sensors to this platform (e.g., a transmissometer). These sensors are planned to be installed in the central cluster.

- Narrow-Field-of-View Zenith Sky Radiance in the Near Infrared, in Progress. An uplooking near-IR shortwave radiance instrument with a field of view overlapping or nearly coincident with the MWR and possibly the cloud radar is being developed. The wavelengths detected are in a fairly narrow band near $0.9 \mu \mathrm{m}$. Such a device is needed to improve understanding of the relationships between the liquid water path and shortwave radiation.

- Ground Radiation Measurement System, in Progress. The design and assembly are underway. Two sets of GRAMS sensors will be used, one for installation at the optical trailer cluster and the other on the deck of the RCF. Each set has a total shortwave broadband radiometer (TSBR), a fractional solar broadband radiometer (FSBR), and a total direct diffuse radiometer (TDDR). Both sets will be installed this summer.

- Optical Transmissometer, in Progress. A commercially available transmissometer will be acquired to detect fog, dust, and drizzle too light to be recorded by rain gauges. Such phenomena are best detected by open-path devices rather than through a large sampling stack such that as being used with the aerosol observation system (AOS). The data will be useful for evaluation of signals from radars, lidars, and the MWR. 
- Establishment of Instruments at an Extended Facility at a Forested Site, in Progress. A walk-up scaffolding tower (approximately $55 \mathrm{ft}$ ) for supporting an ECOR system, a surface meteorological observation station (SMOS), and a SIRS above the forest canopy at the Okmulgee extended facility is being acquired. Phased implementation will begin with the installation of an access road, power, and the walk-up tower this summer. This site may not be fully operational until spring 1998.

- Ceilometers and AERIs at Boundary Facilities, in Progress. Four Vaisala ceilometers have been acquired for installation at the boundary facilities this year. These ceilometers are capable of detecting cloud base to a height of about $7.5 \mathrm{~km}$. These ceilometers are intended primarily to provide data for algorithms to retrieve temperature and humidity profiles in the lower troposphere from AERI data. Delivery and phased installation of the AERIs are to begin with the first AERI installed at Purcell this fall.

- Solar Spectral Radiometer, in Progress. A field spectroradiometer system for wavelength ranges of $350-2,500 \mathrm{~nm}$ in three wave bands is being acquired. Initially, only global radiation will be detected. Installation is expected this summer.

- Occasional Tethersonde and Kite Measurements of Humidity Profiles at the Central Facility, in Progress. A tethersonde system and a kite system outfitted with a high-quality humidity sensor repeatedly made measurements of temperature and relative humidity profiles in the lower $1 \mathrm{~km}$ of the atmosphere above the central facility during the Water Vapor IOP in September 1996. These systems will be used in future IOPs.

- Upgrades of the Radiosonde System, in Progress. Steps have been taken to upgrade the CART BBSSs to use GPS-based rather than loran-based tracking for determining position, which will be necessary during the next few years as Loran- $\mathrm{C}$ transmitters are phased out. In addition, a new type of Vaisala radiosonde, which uses the RS-90 sonde instead of the RS-80 version presently used, is expected to become available within a year. The humidity sensor on the RS-90 sondes is reported to have a faster response and to recover more quickly after emerging from clouds. The temperature sensors 
are smaller and thus probably considerably faster in response and less susceptible to the effects of heating by solar radiation. In addition, reference temperature, humidity, wind, and pressure sensors (THWAPSs) were installed at the balloon launch site at the central facility to provide surface reference values. A THWAPS will be installed at each of the boundary facilities during this six-month period.

- Rotating Shadowband Spectrometer, in Progress. An RSS was tested at the SGP central facility during the fall of 1996 after extensive development and testing at the Atmospheric Sciences Research Center (ASRC) at the State University of New York. Steps are being taken by ASRC and site operations to implement the RSS on a long-term basis at the SGP central facility, to measure the solar spectrum between approximately 350 and $1,050 \mu \mathrm{m}$ for the direct, diffuse, and global components. Installation is expected during the summer of 1997.

Measurement issues currently being considered but unresolved by the ARM infrastructure include the following:

- Continuous Direct-Beam Solar Irradiance Measurements with a Cavity Radiometer. Documentation for the BSRN specifies that an all-weather windowless cavity radiometer be operated at the BSRN site. This task is not feasible at the SGP CART site central facility because of dust conditions. Operation of a windowed cavity radiometer, one of which has already been purchased for this purpose, might be possible at the RCF, but considerable effort would be necessary for continuous operation. Some compromise for part-time or discontinuous operation might have to be developed.

- Absolute Solar Transmittance Interferometer and Solar Radiance Transmission Interferometer. Support of absolute solar transmittance interferometer (ASTI) development is occurring in the IOP mode for the shortwave portion of the Fall 1997 Integrated IOP. Solar radiance transmission interferometer (SORTI) implementation at the central facility is proceeding. Data are being collected, but ingest has not been achieved. 
- Local Observations of Surface Vegetative Conditions at Extended Facilities. The interpretation of data on, and the modeling of, surface latent and sensible heat fluxes at extended facilities would be assisted with routine observation of leaf area index and surface optical reflectance properties represented by the nondimensional vegetative index. Local leaf area index measurements might be too variable to be of much use, but local measures of nondimensional vegetative index were believed to be particularly important for interpretation of nondimensional vegetative index values derived from remote sensing data from satellites. The satellite could then be used to help infer the values and variability of surface heat fluxes for the overall SGP CART site. Relatively simple devices that obtain a measure of nondimensional vegetative index can be obtained at a modest cost and are currently being investigated.

- Additional Extended Facilities at the SGP CART Site. Some concern has been expressed that the spatial coverage of extended facilities for measuring airsurface exchange rates of heat and moisture seems to be incomplete, particularly to the south and southeast of the central facility. A review of the current site distribution needs to be carried out.

- Surface Bidirectional Reflectance. Measurements of surface bidirectional reflectance have been suggested at times for the SGP CART site, and a commercial source of the portable apparatus for rapid acquisition of bidirectional observations of the land and the atmosphere (PARABOLA) is available. Such an observation would be quite useful in the interpretation of solar reflectances seen from satellites. A commercial system is available but is not suitable for routine observations. Currently, a new Science Team project is addressing this observational need.

- Profiling with Passive Microwave Systems. A passive MWR for obtaining profiles of temperature through clouds could augment or supplant profile measurements made with the AERI at the boundary facilities. The primary advantage of microwave profiling is that it penetrates through clouds, which is not accomplished with any of the water vapor remote sensing systems currently in operation at the SGP CART site. Radiometrics has been developing such a radiometer. Vertical resolution appears to be about $100 \mathrm{~m}$ near the surface and increases gradually to over $2 \mathrm{~km}$ at a height of about 
$10 \mathrm{~km}$ near its maximum range. A less expensive Russian system with slightly greater vertical resolution and a maximum range of about $600 \mathrm{~m}$ is currently being evaluated. If funding were provided, a passive system for water vapor profiling might also be successfully developed.

\subsection{Observations, Measurements, and External Data}

The ARM observations being delivered to the Experiment Center from the SGP CART site as of June 30, 1997, can be found on the WWW at

http://www.ec.arm.gov/data/sgpmeasurement.html .

External data being delivered to the ARM Program can be found on the WWW at

http://arm3.das.bnl.gov/sisg/ext.html .

The availability of data from a particular platform on any given day is a function of quality control, with some segments temporarily unavailable during evaluation or correction of problems.

A summary that includes both the measurements derived from the SGP CART data and data streams from sources external to ARM (e.g., the gridded data from the National Centers for Environmental Prediction model [ETA]) can be found on the WWW at

http://www.ec.arm.gov/data/sgpavailability.html .

\subsection{Site Development Activities}

\subsubsection{Facilities}

Full implementation of the El Reno extended facility will not take place until after the Hydrology IOP, pending the approval of a Memorandum of Understanding between Argonne National Laboratory and the USDA. A temporary setup of a solar-powered EBBR and SWATS with cellular phone data communications is in place for this IOP. 
Implementation of the Okmulgee extended facility will take place in five phases. The first will be an access roadway and power. The second will be the installation of the walk-up tower. The third phase will include the installation of the infrastructure (cement pads, data communication lines, gravel, etc.). The fourth phase will be the installation of the shelter and security fence. The fifth phase is the installation of the instruments. Full implementation is not expected until the end of this six-month period.

The number of radiometers to be deployed at the central cluster has required expansion and an additional area designated as the optical trailer cluster. Instruments critical to the Fall 1997 Integrated IOP will be installed and operational there in August 1997. They include the GRAMS, TLCV, RSS, and CSPHOT. In addition, the ultraviolet A (UV-A), UV-B, and PAR sensors will be located on one of the spare posts in the SIROS array. A narrow-field-of-view zenith-pointing filtered radiometer (NFOV) will be deployed near the EBBR. The shortwave spectrometer (SWS) and the ASTI will be considered for installation in the optical trailer. Each of the cluster areas has been upgraded to allow for expansion of yet unspecified instruments.

In anticipation of additional IDP area facilities, IDP No. 4 is being implemented. This $150-\mathrm{ft} \times 175-\mathrm{ft}$ graveled area will be located at the site formerly occupied by the farmhouse at the extreme southeast corner of the central facility. This area will have a double-wide trailer ( $24 \mathrm{ft} \times 55 \mathrm{ft}$ ) for storage and a $12-\mathrm{ft} \times 50$ - $\mathrm{ft}$ office trailer. This IDP area is anticipated to be available for the Fall 1997 Integrated IOP.

\subsubsection{Development of the Site Data System}

Several of the installed instruments and all new instruments will require creation of software to transfer the data from the instrument platforms to the SDS via a pathway referred to as the integrated data processing circuit (IDPC). The IDPC includes communications between the instrument and data loggers, as well as data ingest (described more fully in Section 4.1), instrument status to site operations and others, and, finally, transmission of data to the Experiment Center and the Data Archive. Usually, transfer of data is accomplished by coded switches at the extended facilities and intermediate facilities or by $\mathrm{T}-1$ lines at the boundary facilities. Most of the ARM SGP instruments have their data collected (or delivered) to the SDS regularly, with data processed through the IDPC and passed on to the Experiment Center and the ARM Archive. Some exceptions to this pattern will continue to occur during the next six months. 
The IDPC development schedule and status for instruments can be found at the WWW site:

http://kombo.dis.anl.gov/armtrack .

To access this database, $\log$ in as "guest"; and type in "guest" for the password, and specify "IDPC" as type. Further work is being undertaken to facilitate routine operations and particularly to assess instrument performance, by including a broader suite of data display capabilities. Once the SDS is near completion, procedures for system management and maintenance need to be written and transferred to site operations staff. In 1996, site operations management hired a site computer systems administrator, who facilitates local SDS development, operation, and maintenance.

In addition, the SDS continues to address the ongoing need to make near-real-time data available for selected scientists during IOPs and campaigns and for educational outreach efforts in conjunction with the Oklahoma Climatological Survey's EARTHSTORM project. A successful prototype system for delivering near-real-time data to scientists was used during the Water Vapor IOP of September 1996. This Web-based system, known as the R1 or Research System, has been formalized recently for use in future IOPs.

\subsection{Limiting Factors}

The most basic of limiting factors is the amount of resources available to continue site development, expand operations, and provide necessary support for the IT and DSIT. Shortfalls result in delays in implementation. Shortfalls in vendor supplies, delays in obtaining information for PRRs, and budgeting problems have also been hindrances. Other significant limiting factors are the time lags inherent in the procurement process and the calibration of radiometers before installation, though the latter should be relieved by the presence of the new calibration facility.

All systems awaiting construction or installation go through a formal design review of structural and mechanical systems. These reviews frequently identify deficiencies in plans and drawings related to engineering requirements, procurement details, safety, and quality control. This review activity was expanded to include large or complex IOPs (e.g., the ARESE IOP in September 1995) in an effort to integrate the exceptionally wide variety of IDP instrument support requirements for cost-effective and safe implementation. Neither construction nor installation can begin until the design review process has been successfully completed. 
The costs associated with BBSS launches (primarily expendables) will continue to be a burden on the operations budget until these systems are replaced by continuous, unmanned remote sensing systems, if ever. These expenses are a strong constraint on the total number and frequency of launches, making impossible the routine provision of all of the requested launches (eight per day at the central and boundary facilities), defined as the optimal sounding strategy for SCM requirements by the DSIT (M. Bradley and R. Cederwall, unpublished information). 


\section{DATA QUALITY}

Data quality issues are addressed at several levels within the ARM Program and at the SGP CART site. One of the goals of the ARM Program is to provide data streams of known and reasonable quality. Maintaining data quality for a program of this size and complexity is a significant challenge. Data quality assurance within the ARM Program infrastructure has matured over the past few years and will continue to evolve, with the SST continuing to develop the stronger role that it assumed during past years.

\subsection{Instrument Mentors}

Instrument mentors are charged with developing the technical specifications for instruments procured for the ARM Program. The instrument mentor then tests and operates the instrument system (either at his or her location or at the SGP CART site). In addition, the mentor works with SDS personnel on ingestion software requirements as part of the IDPC. Data ingestion involves the conversion of data streams to the International System of Units (SI), as well as the acquisition of parameters that can be used to monitor instrument performance (e.g., monitoring an instrument's output voltage for a $5-\mathrm{V}$ power supply or the continuity of the wire in a hot-wire anemometer). Data collection and ingestion, then, are the focus of the first level of data quality assurance. Quality at this level is monitored routinely by site operators and instrument mentors.

The next level of data quality assurance involves beta release of data streams from individual instruments. The mentor receives the data from the instrument to determine whether the technical specifications of the instrument are being met. When the mentor is satisfied that the instrument is functioning properly and that the technical specifications have been met, the data are formally released to the Science Team and other data users. After this release, the instrument mentor is also charged with reviewing the instrument data streams at least once every two weeks, an action monitored at the Experiment Center. This information is forwarded to the SST.

Instrument mentors also provide all operations and maintenance documents and lists of spare parts to site operations. Typically, the mentor provides additional detailed documentation and hands-on training so that appropriate support can be provided by site operators. This activity is part of the ORR process. 


\subsection{Site Scientist Team}

The SST helps to ensure that the scientific productivity of the SGP CART site is maximized by both the routine and special (IOP) operations at the site. The SST acts as a resource for the site operations manager and his staff on scientific matters related to instrument data streams by doing the following:

- Fielding and answering questions from site operations personnel concerning potential instrument problems

- Reviewing proposed instrument siting and deployment strategies, including the needs of the instrument mentors and instrument requirements for IOPs and campaigns

- Reviewing schedules and procedures for instrument calibration and maintenance

- Providing an early assessment of suspected instrument or data problems through the use of performance metrics, graphic display techniques, and data quality research investigations, and distributing their findings so that corrective actions can be taken

These activities require constant communication with site operations staff, including routine visits to the central facility and occasional trips to extended, intermediate, and boundary facilities. These activities are also highly coordinated with the site program manager and, when appropriate, with instrument mentors and DSIT personnel. Ongoing focus activities of the SST will contribute to the goals of data quality assessment for the SGP CART site and ensure that the operation of the site meets, as nearly as possible, the overall scientific goals of the ARM Program.

Recently, the SST placed an announcement to hire an on-site representative to help perform first-line-of-defense quality data assurance, develop tools to perform data quality assurance, perform data quality investigation research on problems that require special attention, interact closely with the on-site operations manager and his staff at the central facility on all science-related activities, help in the planning and operation of IOPs, and help conduct on-site outreach activities. This newest member of the SST is anticipated to be on-site by summer. 
In the past, data quality assessment efforts of the SST largely involved evaluation of individual and multiple sets of data streams as needed, on an exploratory or developmental basis (data quality investigations); participation in QMEs; and participation in the creation and workings of the VAP Working Group.

Now that operational activities have shifted from deployment to support of ongoing, continuous operation of a wide variety of instrumentation at many locations, a more comprehensive, systematic data quality assessment effort has been undertaken by the SST. This effort is manifested in several ways, including the evaluation of the calibration and maintenance information, the development and use of automated, graphic display techniques for use by the SST and site operators in daily monitoring of data quality (work began in October 1995), and the development of performance metrics that systematically determine what percentage of the collected data falls within given quality tolerances (work began in February 1996).

The development of performance metrics is aimed at systematically determining the data "health" of the site via time series (numerical and graphic) of the metrics. The ultimate format of this presentation is under development. In late 1996, the SST began issuing SIROS data assessments with the goal of attaining quicker resolution of instrument and data quality problems. In spring 1997, this weekly data quality assessment, currently available via E-mail, was expanded to include all data streams, with input not only from the SST, site operations, and instrument mentors, but also from DSIT staff, who look at VAP and QME performance and data existence. Plans for this six-month period and beyond include development of graphic display technique scripts for more data streams, the development of explicit guidance materials to allow site operations staff to use the display techniques effectively, continued development of performance metrics, and continued evaluating of the calibration and maintenance information, with an eye on developing presentation formats for use by different groups such as site operations and actual data users. Thus, with the assistance of the site operations staff and instrument mentors, the SST will be able to serve the ARM Program goals better by laying a foundation for improving data credibility.

Finally, a new ARM-wide initiative aimed at ensuring the quality of shortwave radiation data began during the latter half of 1996 . The backbone of this tracking system will be performance metrics developed by the Site Scientist and SIROS instrument mentor and produced and packaged in near real-time by the DSIT. Components of this tracking system cover 10 measurement components: downward hemispheric flux, direct broadband component, diffuse broadband component, direct spectral component, diffuse spectral component, optical depth, net 
shortwave surface radiation, broadband albedo, spectral albedo, and calculated quantities (zenith angle, effective top of atmosphere horizontal flux). Performance metrics for some of these components already exist; others do not. The hope is to have an analysis product up and running by August 1997 .

\subsection{Value-Added Products and Quality Measurement Experiments}

Unlike many other scientific projects, ARM collects data in an ongoing, continuous manner. Because of the volume of these perpetual data streams, traditional case study methods for analyzing these data are not very effective. To fit the need for an automatic analytical approach, the concept of a VAP (value-added product) has been defined. A VAP creates a "second-generation" data stream by using existing ARM data streams and inputs and applying algorithms or models to them. A VAP is run continuously in the ARM Experiment Center, and the output generated is treated as a new ARM data stream.

Many of the scientific needs of the ARM project are met through VAPs. Physical models that use ARM instrument data as inputs are implemented as VAPs and can help fill some of the unmet measurement needs of the program. A special class of VAPs called QMEs compare different data streams for consistency and allow for continuous assessment of the quality of the ARM data streams. These data streams may come from direct measurements, measurements derived from instrument observations via other VAPs, or model output that is currently created by other VAPs.

New VAPs or suggestions of improvements or modifications to existing VAPs come from all aspects of the ARM program: the Science Team, instrument mentors, the DSIT, the Archive, the SST, etc. However, because of the limited resources available, VAP development must be prioritized in a meaningful matter. To this end, the VAP Working Group was established. This group consists of members of the infrastructure that crosscut the program, with representatives from each of the major scientific areas of ARM. This group discusses the scientific objectives of each VAP in the development queue, looks for common threads among them, assigns priorities, estimates completion dates, and assists in the development of the VAPs. The SST is represented on the VAP Working Group. Value-added products currently available are given in Table 3. More information is available on the WWW at 
TABLE 3 Value-Added Products in Place at the SGP CART Site ${ }^{a}$

Value-Added Product

Description

LBLRTM

QME AERI/LBLRTM

QME MWR/LBLRTM

QME AERI/LBL CLOUDS

RWP TEMP

MWR PROF

QME MWR PROF

AERI PROF

QME AERI PROF

QME MWR COL
Line-by-line radiative transfer model; used for longwave and

microwave radiance calculations

Comparisons of observed (AERI) vs. calculated (LBLRTM)

longwave downwelling radiation

Comparisons of observed (MWR) vs. calculated (LBLRTM)

microwave radiance at two frequencies

State-of-the-atmosphere data to facilitate QME AERI/LBLRTM analysis

Merged and quality-controlled RASS virtual temperature profiles

Retrievals of water vapor, liquid water, and temperature profiles from a suite of ground-based instruments

Comparisons of retrieved water vapor and temperature profiles from MWR PROF with BBSS profiles

Retrievals of temperature and water vapor from the AERI data

Comparisons of retrieved water vapor and temperature profiles from AERI PROF with in situ measurements

Comparisons of the MWR with an instrument performance model

a AERI, atmospherically emitted radiance interferometer, BBSS, balloon-borne sounding system; LBL, line by line; LBLRTM, line-by-line radiative transfer model; MWR, microwave radiometer; PROF, profile; QME, quality measurement experiment; RASS, radio acoustic sounding system; RWP, radar wind profiler; TEMP, temperature. 


\subsection{Problem Review Board}

For a large data collection program, procedures must be in place to facilitate the documentation of problems and their associated resolutions. The ARM Program is tasked with creating data of "known and reasonable" quality. To achieve this quality, the Problem Review Board (PRB) facilitates the resolution of problems identified by "anyone" involved in the ARM data pipeline. The Problem Identification Form (PIF) and Corrective Action Report (CAR) are reports that allow a formal mechanism for capturing information about potential problems, the potential impact on the quality of the data, and the correction action needed to resolve the problem.

The goal of the PIF/CAR system is to provide "end-to-end" problem management. No single person has the expertise to correctly resolve all classes of problems that might be identified in the ARM Program. The PRB technically reviews all incoming PIFs for their immediate impact on data connection and quality and assigns responsibilities for their correction and response (i.e., CAR).

The PRB is a small multilaboratory team with a broad base of membership. It is composed of a chairman, an oversight individual, and a representative from each of three teams: the IT, the Site Operation Team, and the DSIT. The PRB oversees the assignment of problemsolving actions as triggered by PIFs and the resolution of the problems as documented in CARs.

A PIF should document anything that impacts the data system or that more than one person needs to know or learn from. Not every PIF will identify a real problem. In some cases, the PIF will identify a misunderstanding or someone's need for more information. Some problems will have an obvious solution, but the timing of the corrective action may need to be coordinated with other subsystems within the project. Some problems will require further analysis to be understood, and some problems may just require documentation because no clear solution can be identified at the time. A review of the PIF is required before the PIF is accepted as a problem and before it is actually scheduled for resolution. The CAR documents the details of the resolving action. The corrective action required is an end-to-end problem solution, not just a fix in a software module.

In addition, a Data Quality Report ( $(\mathrm{QR})$ may be required. $A D Q R$ is a statement about the quality of data from a particular instrument. Usually, a $D Q R$ is generated by an instrument mentor. If not generated by the mentor, it must be reviewed by the mentor. The $D Q R$ 
information could be quite simple (e.g., stating that an instrument system was turned off during certain time periods because of unexpected hardware problems), but it could also be quite complex, giving detailed analysis and equations that should be used to adjust the instrument's observational data. One advantage of the DQR in comparison with a PIF is that the DQR form is simpler. It is easier to fill out and less cumbersome to incorporate into a data stream. If a large amount of processing of data is implied or requested in the DQR, reprocessing could be delayed for a long time. Hence, the description of the problem and the fix must be complete, so that someone can accurately reprocess the data several months after the date of the DQR submission, if required.

The PIFs should continue to be used to request action by others, or oneself, to find a solution to a problem or generate information on it. A borderline case might be to state that data should be flagged during data ingest as a result of quality control algorithms provided as part of the form submitted. In this case, a PIF rather than a DQR is favored because a specific type of implementation is being requested. On the other hand, application of data quality control algorithms to data already collected and resident in the Experiment Center or the Archive would be best handled with a DQR. DQRs tend to be retrospective.

In case of doubt on whether to use a PIF or a DQR, using a PIF is better because it will automatically be examined by the PRB to see if the PIF should be converted to a DQR. If data flagging of an algorithm needs to be implemented both retrospectively and on the current data ingest, consider splitting the request into two parts: a PIF and a DQR.

The PIF/CAR/DQR database can be found at

http://www.db.arm.gov/ARM/PIFCARDQR/ . 


\section{SCIENTIFIC INVESTIGATIONS AND OPPORTUNITIES}

In 1994, the ARM Program identified a need for the creation of a SAC to provide assistance to the ARM Program Science Team, the SGP CART SST, and the SGP CART site program manager. The SAC's charter is to

- Evaluate the SGP CART site scientific mission,

- Provide scientific mission guidance for SGP CART site operations,

- Evaluate the research program of the site scientist,

- Evaluate the potential for collaboration with other research programs, and

- Provide recommendations for the SGP CART site educational outreach program.

The seven-member SAC is composed of ARM and non-ARM Program scientists who meet formally at least once per year. The first such meeting was held in November 1995 at the University of Oklahoma (OU), and a second follow-up meeting was held in June 1996. A written report summarizing the SAC's recommendations on the basis of the first meeting was distributed in early 1996 to the ARM Management Team, the SST, the site operations manager, and the site program manager and was responded to in writing by the SST. The report from the June meeting was finalized in early 1997. Individual committee memberships last for three years.

\subsection{Intensive Observation Periods}

The SGP CART site operates a vast suite of instrumentation that routinely provides continuous data streams at a prescribed rate. These rates, however, can be changed upon request. Requests from inside and outside the ARM Program can be made through the SGP CART site program manager's office either (1) to operate an ARM instrument or instruments at a different data collection rate or mode of operation or (2) to support and compare non-ARM instruments with ARM instruments. Those periods are referred to as IOPs. 
The requests can be made by the ARM Science Team, ARM Program infrastructure, or the scientific community at large. Preference for IOPs is given to the ARM Science Team and infrastructure. The ARM Program has a limited budget for IOP support. However, funding from sources other than the ARM Program can be accepted to support IOPs.

The BBSS is the instrument most frequently requested to operate in an accelerated data collection rate and is the primary driver of IOP requests. The SGP CART site has five locations where BBSS instruments are operated routinely. When operated in an accelerated data-rate mode, simultaneous radiosonde launches can be made every three hours at all five locations for a 21-day period or longer.

The ARM Program provides funding for a total of 3 three-week-long, accelerated BBSS launch periods per year, which are referred to as SCM IOPs. Two SCM IOPs are held at fixed time periods, one in spring and one in summer. The third SCM IOP alternates between winter and fall. Although the ARM Program supports and encourages multiple, concurrent IOPs during SCM IOP periods, IOPs involving accelerated BBSS launches at other times of the year will be considered as budget allows.

Requests for IOPs come through the SGP CART site program manager's office. The initial requests can be made informally, but an abstract of the goal(s) of the experiment(s) being requested, a list of the potential instruments and platforms involved, and the time period of the experiment(s) must be provided for approval. Requester coordination points of contacts are identified.

Approval of an IOP is an external process that requires (1) review for resources and relevancy and (2) approval by the ARM Program Technical Director, the SGP CART site program manager, the SST, and site operations. Once approved, the management of the detailed planning, setup, conduct, and shutdown of the IOP is the responsibility of the site program manager.

An IOP is given a title and assigned a DSIT representative. The DSIT representative has the responsibility to obtain the relevant scientific information about the proposed activity, which is typically obtained in a science plan. The DSIT representative has the responsibility to inform ARM Science Team members of the proposed activity for the purpose of potential collaboration. 
The site program manager obtains a list of potential principal investigators (PIs) and the instrument or systems that are intended to be located at the SGP CART site from the DSIT representative. The site program manager then sends the IOP questionnaire to the PIs to collect information critical to the operation, safety, and data requirements for the IOP. The IOP questionnaire is returned to the site program manager's office and distributed to the appropriate ARM infrastructure for review. The IOP questionnaire can be entered directly by a PI at the WWW site:

http://www.arm.gov/stdocs/internal/iop_form.html .

The ARM infrastructure groups include the SGP CART site program manager, the SGP CART site SDS team, the DSIT representative, the SST, and site operations. Each of the ARM infrastructure groups has a specific role in the planning and implementation of the IOP.

The DSIT representative assesses the data requirements: those requested by the participating PI from ARM and those to be provided to ARM by the PI. A schedule of data delivery is determined. Also, the DSIT will maintain a Web site that provides information about IOP planning and status, as well as day-to-day operations activities during the IOP. The main elements of this new Web site will include a science plan, each PI's IOP questionnaire, the IOP operations plan, and a daily log during the IOP that identifies and discusses each day's scientific mission.

The SGP CART site SDS team assists PIs that have requested Internet connections at the SGP CART site central facility. The SDS team assists with the actual interface, as well as establishing limitations to the size of data files and the actual time of data file transfers so that the PI data transfers do not impact the SGP CART site data transfer schedule.

The SST has the overall responsibility for coordinating scientific interactions at the SGP CART site. The SST personnel work with the DSIT representative to identify IOP scientists. The SST assists the site program manager and site operations in locating instrumentation at the SGP CART site. The SST personnel assist in identifying real-time display requirements during IOP operations and identify mission-critical data streams that must be maintained during the IOP.

Site operations personnel provide IOP safety oversight and support installation of all guest instruments in accordance with requirements identified in the IOP questionnaire. The site 
operations personnel maintain the operational status of SGP CART site instrumentation and provide triage (quick-response maintenance) for those instruments with data that have been identified as critical to the IOP. The operations staff provide PIs with additional logistical support (e.g., liquid nitrogen supplies, phone lines, safety briefings, and power) in accordance with requirements identified in the IOP questionnaire.

The site program manager's office manages the coordination of all activities associated with the IOP. The site program manager's office produces an IOP operations plan that will identify all of the activities associated with IOPs, including roles and responsibilities, identification of mission-critical instruments and an instrument triage plan, the locations of instruments and use of SGP CART site facilities, safety and emergency actions, IOP termination and start-up procedures, and a list of participants.

The progress of IOP planning activities is monitored via the weekly SST conference call that takes place on Tuesdays at 11:00 a.m. central time and through other as-needed conference calls with IOP participants and ARM infrastructure personnel. The IOP Web interface page functions as a tool to facilitate the coordination and flow of information during all phases of IOP planning, implementation, and operation. The site program manager will provide monthly updates in his internal monthly reports. Past, present, and known future IOPs are listed in Table 4.

\subsection{Intensive Observation Periods for this Six-Month Period}

The IOPs of key scientific interest during this upcoming six-month period (or which will be occurring partially at the beginning of this six-month period) are discussed in the following paragraphs (also see Table 4).

The Spectral Imagery Technology Applications Center IOP. The purpose of this IOP is to acquire data to obtain ground truth measurements and to improve atmospheric compensation models. The primary goal is to analyze approaches to atmospheric compensation on hyperspectral and ultraspectral image data obtained from satellite platforms. Two independent five-day activities have been scheduled. The first took place December 6-10, 1996, and the second five-day activity took place the week of June 23, 1997. The Spectral Imagery Technology Applications Center (SITAC) IOP involves an aircraft and support provided by SITAC participants. The DSIT representative for this IOP is Don Slater, Pacific Northwest National Laboratory (PNNL), who can be reached at (509) 372-6049. 
TABLE 4 Intensive Observation Periods

\begin{tabular}{|c|c|c|c|c|c|}
\hline Date & Name & $\begin{array}{l}\text { Science Team } \\
\text { Membera }^{l}\end{array}$ & $\begin{array}{c}\text { DSIT } \\
\text { Contact }^{\circ}\end{array}$ & Description & Status \\
\hline $11 / 92$ & $\begin{array}{l}\text { Field Test of NCAR } \\
\text { Flux Profiler }\end{array}$ & D. Parsons (NCAR) & R. Cederwall & $\begin{array}{l}\text { Enhanced soundings at the central } \\
\text { facility and profiler site were made } \\
11 / 10-11 / 19 ; \text { boundary layer flights } \\
\text { were also conducted on a few days. }\end{array}$ & Completed; data available \\
\hline $4 / 93$ & AERI Ficld Test & H. Revercomb (UW) & J. Liljegren & $\begin{array}{l}\text { Enhanced soundings at the central } \\
\text { facility were requested during the field } \\
\text { acceptance test of the AERI } \\
\text { instrument. }\end{array}$ & Completed $4 / 29 / 93$ \\
\hline $\begin{array}{l}5 / 93- \\
6 / 93\end{array}$ & $\begin{array}{l}\text { Using the GPS for the } \\
\text { Measurement of } \\
\text { Atmospheric Water } \\
\text { Vapor }\end{array}$ & $\begin{array}{l}\text { Collaborative } \\
\text { (UNAVCO and NCSU) }\end{array}$ & J. Liljegren & $\begin{array}{l}\text { The purpose was to test the } \\
\text { investigators' technique for inferring } \\
\text { total precipitable water vapor in the } \\
\text { atmosphere column by using GPS } \\
\text { signals. }\end{array}$ & $\begin{array}{l}\text { Completed 6/8/93; data } \\
\text { available }\end{array}$ \\
\hline $6 / 93$ & $\begin{array}{l}\text { Warm-Season Data } \\
\text { Assimilation and ISS } \\
\text { Test }\end{array}$ & D. Parsons (NCAR) & R. Cederwall & $\begin{array}{l}\text { This test was an enhanced sampling } \\
\text { (in time and space) of the SGP } \\
\text { domain for a 10-d period with profilers } \\
\text { and sondes. The primary goals of the } \\
\text { IOP were (1) to study the performance } \\
\text { of FDDA under thermodynamic } \\
\text { conditions typical of the continental } \\
\text { warm season and (2) to evaluate the } \\
\text { estimates of divergence and vorticity } \\
\text { from the prototype NCAR ISS with } \\
\text { interferometric techniques, the triangle } \\
\text { of three } 915-\mathrm{MHz} \text { profilers, and the } \\
\text { results of FDDA. }\end{array}$ & $\begin{array}{l}\text { Completed; all data } \\
\text { available at the } \\
\text { Experiment Center except } \\
\text { for FDDA, which is } \\
\text { available upon request at } \\
\text { NCAR }\end{array}$ \\
\hline
\end{tabular}


TABLE 4 (Cont.)

\begin{tabular}{|c|c|c|c|c|c|}
\hline Date & Name & $\begin{array}{l}\text { Science Team } \\
\text { Member }\end{array}$ & $\begin{array}{c}\text { DSIT } \\
\text { Contact }^{b}\end{array}$ & Description & Status \\
\hline $\begin{array}{l}1 / 94 \\
4 / 94 \\
7 / 94 \\
10 / 94 \\
4 / 95 \\
7 / 95 \\
9 / 95 \\
4 / 96 \\
7 / 96 \\
4 / 97 \\
6 / 97 \\
9 / 97 \\
10 / 97\end{array}$ & Seasonal SCM IOP & D. Randall (CSU) & R. Cederwall & $\begin{array}{l}\text { Seasonal IOP with enhanced frequency } \\
\text { of observations, particularly vertical } \\
\text { soundings of temperature, water } \\
\text { vapor, and winds at central facility and } \\
\text { boundary facilities for periods of } 21 \mathrm{~d} \text {; } \\
\text { the required sounding frequency is } 8 / \mathrm{d} \text {. } \\
\text { The data are required for quantifying } \\
\text { boundary forcing and column } \\
\text { response. }\end{array}$ & $\begin{array}{l}\text { IOP being planned for } \\
9 / 97\end{array}$ \\
\hline $\begin{array}{l}4 / 94 \\
9 / 95 \\
10 / 95 \\
4 / 96 \\
9 / 96 \\
9 / 97 \\
10 / 97\end{array}$ & ARM UAV & B. Ellingson (UoM) & D. Rodriguez & $\begin{array}{l}\text { Measurements of clear-sky flux } \\
\text { profiles acquired by a UAV and surface } \\
\text { support data are to be used to } \\
\text { understand clear-sky heating rates and } \\
\text { the ability of models to reproduce the } \\
\text { observations. }\end{array}$ & $\begin{array}{l}\text { First IOP conducted } \\
\text { successfully in } 4 / 94 \text {; } \\
\text { flight for ARESE IOP in } \\
9 / 95-10 / 95 \text {; first } 24-\mathrm{h} \\
\text { UAV flight in } 10 / 96\end{array}$ \\
\hline $\begin{array}{l}4 / 94- \\
5 / 94 ; \\
4 / 95- \\
5 / 95\end{array}$ & $\begin{array}{l}\text { Remote Cloud Sensing } \\
\text { Field Evaluation }\end{array}$ & $\begin{array}{l}\text { R. McIntosh (UM); } \\
\text { B. Kropfli (NOAA); } \\
\text { T. Ackerman (PSU); } \\
\text { K. Sassen (UU); } \\
\text { A. Heymsfield } \\
\text { (NCAR); J. Goldsmith } \\
\text { (SNL); and others }\end{array}$ & C. Flynn & $\begin{array}{l}\text { The primary purpose was the field } \\
\text { evaluation and calibration of several } \\
\text { remote sensing cloud-observing } \\
\text { instruments (some from the IDP } \\
\text { project). In situ cloud observations } \\
\text { were critical to the success of this } \\
\text { IOP. Enhanced soundings were } \\
\text { required at the central facility. }\end{array}$ & $\begin{array}{l}\text { Completed; data analysis } \\
\text { in progress }\end{array}$ \\
\hline
\end{tabular}


TABLE 4 (Cont.)

\begin{tabular}{|c|c|c|c|c|c|}
\hline Date & Name & $\begin{array}{l}\text { Science Team } \\
\text { Member }\end{array}$ & $\begin{array}{c}\text { DSIT } \\
\text { Contact }^{\mathrm{b}}\end{array}$ & Description & Status \\
\hline $5 / 94$ & $\begin{array}{l}\text { WB- } 57 \text { Overflight for } \\
\text { the Mcasurement of } \\
\text { Atmospheric Water } \\
\text { Vapor at High Altitude }\end{array}$ & $\begin{array}{l}\text { Collaborative } \\
\text { (Visidyne and Lockhced } \\
\text { PARC) }\end{array}$ & J. Liljegren & $\begin{array}{l}\text { The purpose was to attempt to infer } \\
\text { the vertical distribution of water vapor } \\
\text { at high altitudes from solar } \\
\text { transmission spectra. }\end{array}$ & $\begin{array}{l}\text { Completed; preliminary } \\
\text { transmission spectra } \\
\text { delivered to ARM }\end{array}$ \\
\hline $5 / 94$ & VORTEX IOP & E. Rasmussen (NSSL) & D. Slater & $\begin{array}{l}\text { Special launches were made in support } \\
\text { of VORTEX, testing hypotheses on } \\
\text { the development and dissipation of } \\
\text { severe storms. }\end{array}$ & Completed 5/31/94 \\
\hline $8 / 94$ & $\begin{array}{l}\text { GEWEX/GCIP/GIST } \\
\text { IOP }\end{array}$ & Collaborative & T. Cress & $\begin{array}{l}\text { Special launches were made in support } \\
\text { of the GCIP and GIST as part of an } \\
\text { effort to improve climate models by } \\
\text { improving parameterizations of } \\
\text { hydrologic and energy cycles. }\end{array}$ & $\begin{array}{l}\text { Successfully conducted in } \\
8 / 94\end{array}$ \\
\hline $\begin{array}{l}9 / 94- \\
10 / 94 \\
6 / 95- \\
7 / 95\end{array}$ & $\begin{array}{l}\text { Sampling of Coherent } \\
\text { Structures with the } \\
\text { 915-MHz Profiler }\end{array}$ & R. Coulter (ANL) & R. Cederwall & $\begin{array}{l}\text { Fluctuations in the vertical wind and } \\
\text { index of refraction were observed by } \\
\text { operating the } 915-\mathrm{MHz} \text { profiler with } \\
\text { RASS in a special mode during the } \\
\text { afternoon hours to sample convective } \\
\text { plume structures. }\end{array}$ & Completed \\
\hline
\end{tabular}


TABLE 4 (Cont.)

\begin{tabular}{|c|c|c|c|c|c|}
\hline Date & Name & $\begin{array}{c}\text { Science Team } \\
\text { Member }\end{array}$ & $\begin{array}{c}\text { DSIT } \\
\text { Contact }^{b}\end{array}$ & Description & Status \\
\hline $\begin{array}{l}4 / 95 \\
5 / 95\end{array}$ & $\begin{array}{l}\text { Simultaneous Ground- } \\
\text { Based, Airborne, and } \\
\text { Satellite-Borne } \\
\text { Microwave Radiometric } \\
\text { and In Situ Obscrvations } \\
\text { of Cloud Optical } \\
\text { Properties and Surface } \\
\text { Emissivities }\end{array}$ & $\begin{array}{l}\text { W. Wiscombe (NASA- } \\
\text { GSFC); E. Westwater } \\
\text { (NOAA-ETL) }\end{array}$ & D. Slater & $\begin{array}{l}\text { Observations of cloud optical } \\
\text { propertics were obtained over the } \\
\text { CART site simultaneously from } \\
\text { ground-based, in situ, and satellite- } \\
\text { borne sensors; spatial variability of } \\
\text { surface emissivities was assessed to } \\
\text { attempt retrieval of total precipitable } \\
\text { water and cloud liquid water from the } \\
\text { special sensor microwave imager. }\end{array}$ & $\begin{array}{l}\text { Completed; involved } \\
\text { collaboration between } \\
\text { Wiscombe and L. Fedor at } \\
\text { NOAA }\end{array}$ \\
\hline $\begin{array}{l}4 / 95 \\
5 / 95\end{array}$ & VORTEX-ARM & $\begin{array}{l}\text { E. Westwater (NOAA- } \\
\text { WPL); W. Wiscombe } \\
\text { (NASA-GSFC); } \\
\text { G. Stephens and } \\
\text { P. Gabriel (CSU); } \\
\text { J. Schneider } \\
\text { (CIMMS/NSSL) }\end{array}$ & D. Slater & $\begin{array}{l}\text { A joint VORTEX-ARM proposal was } \\
\text { approved for } 45 \text { h of P-3 aircraft time } \\
\text { to study stratocumulus clouds. Work } \\
\text { was coordinated with Remote Cloud } \\
\text { Sensing IOP. }\end{array}$ & $\begin{array}{l}\text { Data exchange completed } \\
12 / 95\end{array}$ \\
\hline $\begin{array}{l}6 / 95- \\
7 / 95\end{array}$ & $\begin{array}{l}\text { Surface Energy } \\
\text { Exchange IOP }\end{array}$ & $\begin{array}{l}\text { C. Doran (PNNL); } \\
\text { R. Coulter (ANL); } \\
\text { R. Stull (UBC) }\end{array}$ & R. Cederwall & $\begin{array}{l}\text { Detailed observations of the } \\
\text { temperature and moisture profiles in } \\
\text { the PBL obtained within a radius of } \\
75-125 \mathrm{~km} \text { of the central facility by } \\
\text { using airsondes and profilers to } \\
\text { evaluate the variations of the PBL } \\
\text { structure in relation to underlying } \\
\text { surface fluxes. }\end{array}$ & $\begin{array}{l}\text { Completed; airsonde data } \\
\text { available as beta release } \\
\text { from C. Doran }\end{array}$ \\
\hline
\end{tabular}


TABLE 4 (Cont.)

\begin{tabular}{|c|c|c|c|c|c|}
\hline Date & Name & $\begin{array}{l}\text { Science Team } \\
\text { Member }\end{array}$ & $\begin{array}{c}\text { DSIT } \\
\text { Contact }^{b}\end{array}$ & Description & Status \\
\hline $\begin{array}{l}9 / 95- \\
10 / 95\end{array}$ & ARESE & Collaborative & T. Cress & $\begin{array}{l}\text { The purpose was to study the } \\
\text { anomalous absorption of solar } \\
\text { radiation by clouds. The phenomenon } \\
\text { was first noticed when satellite } \\
\text { measurements of solar radiation } \\
\text { absorbed by the surface almosphere } \\
\text { were compared with solar radiation } \\
\text { measured at collocated surface sites. }\end{array}$ & $\begin{array}{l}\text { Completed; data are } \\
\text { available }\end{array}$ \\
\hline $\begin{array}{l}4 / 96- \\
5 / 96\end{array}$ & SUCCESS & Collaborative & R. Peppler & $\begin{array}{l}\text { The purpose is to determine the } \\
\text { impact of the current and the future } \\
\text { subsonic aircraft fleet on Earth's } \\
\text { radiation budget and climate. }\end{array}$ & Completed \\
\hline $6 / 96$ & $\begin{array}{l}\text { MSX Satellite } \\
\text { Overflights }\end{array}$ & Collaborative & H. Foote & $\begin{array}{l}\text { The purpose is to provide ground truth } \\
\text { support for the MSX satellite. Nine } \\
\text { MSX sensors operate in the range of } \\
0.12-0.9 \mu \mathrm{m} \text {. A spectral IR imaging } \\
\text { telescope also operates. }\end{array}$ & $\begin{array}{l}\text { Launched on } 4 / 24 / 96 ; \\
\text { SGP CART site flyovers } \\
\text { on } 6 / 17,7 / 15,8 / 12 \text {, and } \\
9 / 9 \text {, and TWP CART site } \\
\text { flyover on 10/13/96; data } \\
\text { exchange in process }\end{array}$ \\
\hline $\begin{array}{l}6 / 96- \\
7 / 96\end{array}$ & CLEX IOP & $\begin{array}{l}\text { G. Stephens } \\
\text { (CSU/CIRA); } \\
\text { J. Davis (CSU/CIRA) }\end{array}$ & R. Cederwall & $\begin{array}{l}\text { Intensified satellite data collection (by } \\
\text { CSU), airborne cloud radar and in situ } \\
\text { microphysical observations, and an } \\
\text { array of ground-based measurements } \\
\text { will be carried out for better } \\
\text { understanding of the nature and role of } \\
\text { middle-level, nonprecipitating cloud } \\
\text { systems. }\end{array}$ & $\begin{array}{l}\text { Completed; data exchange } \\
\text { in process }\end{array}$ \\
\hline
\end{tabular}




\section{TABLE 4 (Cont.)}

\begin{tabular}{|c|c|c|c|c|c|}
\hline Date & Name & $\begin{array}{c}\text { Science Team } \\
\text { Member }\end{array}$ & $\begin{array}{c}\text { DSIT } \\
\text { Contact }^{b}\end{array}$ & Description & Status \\
\hline $\begin{array}{l}7 / 96 \\
8 / 96\end{array}$ & BLX IOP & R. Stull (UBC) & R.Cederwall & $\begin{array}{l}\text { Remote sensing surface fluxes with } \\
\text { instrumentation on the University of } \\
\text { Wyoming King Air; CASES site and } \\
\text { NCAR mobile profiler involved; in } \\
\text { conjunction with 7/96-8/96 SCM } \\
\text { IOP. }\end{array}$ & $\begin{array}{l}\text { Completed; aircraft data to } \\
\text { be available in 1997; } \\
\text { BAMS article submitted }\end{array}$ \\
\hline $\begin{array}{l}7 / 96 \\
8 / 96\end{array}$ & LLJ IOP & D. Whiteman (PNNL) & R. Cederwall & $\begin{array}{l}\text { The purpose is to investigate } \\
\text { oscillations in the characteristics of } \\
\text { the LLJ over the SGP. }\end{array}$ & $\begin{array}{l}\text { Completed; data from } 915 \text { - } \\
\text { MHz profiler run in } \\
\text { modified mode will be } \\
\text { ingested in } 1997 \text { (available } \\
\text { now from R. Coulter at } \\
\text { ANL); Wyoming King } \\
\text { Air data, in collaboration } \\
\text { with R. Clark (MSU), } \\
\text { will be available in } 1997\end{array}$ \\
\hline $\begin{array}{l}9 / 96 \\
9 / 97 \\
10 / 97\end{array}$ & Water Vapor IOP & H. Revercomb (UW) & $\begin{array}{l}\text { R. Peppler/ } \\
\text { M. Splitt/D. } \\
\text { Turner }\end{array}$ & $\begin{array}{l}\text { First of a series of IOPs to take } \\
\text { measurements of water vapor profiles } \\
\text { using many instrument systems to } \\
\text { attempt to define water vapor profile } \\
\text { of the site in support of IRF research } \\
\text { efforts. First in series focused on } \\
\text { lowest kilometer; second in series to } \\
\text { focus on upper altitudes ( } 4-12 \mathrm{~km} \text { ). }\end{array}$ & $\begin{array}{l}\text { Completed; data to be } \\
\text { available in } 4 / 97 \text {; } \\
\text { planning underway for } \\
9 / 97-10 / 97 \text { period; in } \\
\text { conjunction with UAV } \\
\text { and SCM IOPS }\end{array}$ \\
\hline
\end{tabular}


TABLE 4 (Cont.)

\begin{tabular}{|c|c|c|c|c|c|}
\hline Date & Name & $\begin{array}{l}\text { Science Team } \\
\text { Member }\end{array}$ & $\begin{array}{c}\text { DSIT } \\
\text { Contact }^{b}\end{array}$ & Description & Status \\
\hline $\begin{array}{l}12 / 96 \\
6 / 97\end{array}$ & LMS/SITAC IOP & B. Dillman (Lockheed) & D. Slater & $\begin{array}{l}\text { To analyze approaches to atmospheric } \\
\text { compensation on hyperspectral and } \\
\text { ultraspectral image data obtained from } \\
\text { satellite platforms. }\end{array}$ & Completed \\
\hline $4 / 97$ & Cloud Radar IOP & $\begin{array}{l}\text { B. Martner (ETL); P. } \\
\text { Daum (BNL) }\end{array}$ & $\begin{array}{l}\text { D. Rodriguez/ } \\
\text { M.-D. Cheng }\end{array}$ & $\begin{array}{l}\text { Designed to validate retrieval of cloud } \\
\text { microphysics on the basis of newly } \\
\text { installed ARM zenith-pointing } \\
\text { MMCR (developed by NOAA/ETL); } \\
\text { ETL to operate collocated scanning } \\
\text { NOAA/K-band cloud radar; high- } \\
\text { altitude and low-altitude sampling to } \\
\text { be done by two aircraft; aerosol } \\
\text { components to be flown in clear-sky } \\
\text { conditions by low-altitude aircraft. }\end{array}$ & Completed \\
\hline $\begin{array}{l}6 / 97 \\
7 / 97\end{array}$ & $\begin{array}{l}\text { SGP '97 (Hydrology) } \\
\text { IOP }\end{array}$ & $\begin{array}{l}\text { T. Jackson (USDA); } \\
\text { M.-Y. Wei (NASA) }\end{array}$ & R. Cederwall & $\begin{array}{l}\text { Conducted as part of USDA and } \\
\text { NASA campaign to study } 3 \text { "recharge" } \\
\text { events; additional ARM instruments } \\
\text { will be installed at USDA El Reno } \\
\text { extended facility; non-ARM aircraft } \\
\text { with microwave radiometry will be } \\
\text { sensing soil moisture. }\end{array}$ & $\begin{array}{l}\text { In process as of this } \\
\text { writing }\end{array}$ \\
\hline
\end{tabular}


TABLE 4 (Cont.)

\begin{tabular}{|c|c|c|c|c|c|}
\hline Date & Name & $\begin{array}{l}\text { Science Team } \\
\text { Member }\end{array}$ & $\begin{array}{c}\text { DSIT } \\
\text { Contact }\end{array}$ & Description & Status \\
\hline $\begin{array}{l}9 / 97 \\
10 / 97\end{array}$ & Cloud IOP & G. Mace (PSU) & $\begin{array}{l}\text { D. Rodriguea/ } \\
\text { P. Datum } \\
\text { (aircraft } \\
\text { coordinator) }\end{array}$ & $\begin{array}{l}\text { Obtain on-site measurements of cloud } \\
\text { and aerosol properties in cloudy and } \\
\text { clear-sky conditions; single } \\
\text { microphysics aircraft to be flown in } \\
\text { conjunction with ARM UAV } \\
\text { high/low set of airborne platforms } \\
\text { measuring radiometric properties; } \\
\text { unprecedented opportunity to quantify } \\
\text { cloud/aerosol/radiation interactions. }\end{array}$ & $\begin{array}{l}\text { Planning underway; in } \\
\text { conjunction with UAV, } \\
\text { SCM, and Acrosol IOPs }\end{array}$ \\
\hline $\begin{array}{l}9 / 97- \\
10 / 97\end{array}$ & Aerosol IOP & S. Schwartz (BNL) & $\begin{array}{l}\text { M.-D. Cheng/ } \\
\text { P. Daum } \\
\text { (aircraft } \\
\text { coordinator) }\end{array}$ & See above for Cloud IOP. & $\begin{array}{l}\text { Planning underway; in } \\
\text { conjunction with UAV, } \\
\text { SCM, and Cloud IOPS }\end{array}$ \\
\hline $\begin{array}{l}9 / 97 \\
10 / 97\end{array}$ & $\begin{array}{l}\text { Shortwave Radiation } \\
\text { IOP }\end{array}$ & G. Stephens (CSU) & $\begin{array}{l}\text { D. Slater/ } \\
\text { B. McCoy }\end{array}$ & $\begin{array}{l}\text { To focus on both broadband and } \\
\text { spectrally resolved shortwave } \\
\text { measurements, including emphasis on } \\
\text { instrument calibration and } \\
\text { intercomparison; will also evaluate } \\
\text { GRAMS and have UAV/aircraft } \\
\text { component. }\end{array}$ & $\begin{array}{l}\text { Planning underway; in } \\
\text { conjunction with UAV } \\
\text { and Water Vapor IOPs }\end{array}$ \\
\hline $\begin{array}{l}9 / 97 \\
10 / 97\end{array}$ & Fall 1997 Integrated IOP & TBD & $\begin{array}{l}\text { R. Peppler/ } \\
\text { R. Cederwall }\end{array}$ & $\begin{array}{l}\text { Name for the ensemble UAV, SCM, } \\
\text { Water Vapor, Cloud, Aerosol, and } \\
\text { Shortwave Radiation IOPs. }\end{array}$ & Planning underway \\
\hline
\end{tabular}


TABLE 4 (Cont.)

\begin{tabular}{|c|c|c|c|c|c|}
\hline Date & Name & $\begin{array}{l}\text { Science Team } \\
\text { Member }\end{array}$ & $\begin{array}{c}\text { DSIT } \\
\text { Contact }^{\mathrm{b}}\end{array}$ & Description & Status \\
\hline $10 / 98$ & $\mathrm{CO}_{2}$ DIAL IOP & J. Jolin (LANL) & D. Slater & $\begin{array}{l}\mathrm{CO}_{2} \text { DIAL on aircraft will overfly the } \\
\text { site; has potential benefit for water } \\
\text { vapor and aerosols measurements. }\end{array}$ & $\begin{array}{l}\text { Site visit complete; } \\
\text { planning underway }\end{array}$ \\
\hline
\end{tabular}

- Affiliations: ANL, Argonne National Laboratory; BNL, Brookhaven National Laboratory; CIMMS, Cooperative Institute for Mesoscale Meteorological Studies; CIRA, Cooperative Institute for Research in the Atmosphere; CSU, Colorado State University; ETL, Environmental Technology Laboratory; GSFC, Goddard Space Flight Center; LANL, Los Alamos National Laboratory; MSU, Millersville State University; NASA, National Aeronautics and Space Administration; NCAR, National Center for Atmospheric Research; NCSU, North Carolina State University; NOAA, National Oceanic and Atmospheric Administration; NSSL, National Severe Storms Laboratory; PARC, Palo Alto Research Center; PNNL, Pacific Northwest National Laboratory; PSU, Pennsylvania State University; SNL, Sandia National Laboratories; UBC, University of British Columbia; UM, University of Massachusetts; UoM, University of Maryland; UNAVCO, University NAVSTAR Consortium; USDA, U.S. Department of Agriculture; UU, University of Utah; UW, University of Wisconsin; and WPL, Wave Propagation Laboratory.

- Other definitions: AERI, atmospherically emitted radiance interferometer; ARESE, ARM Enhanced Shortwave Experiment; ARM, Atmospheric Radiation Measurement (Program); BAMS, Bulletin of the American Meteorological Society; BLX, Boundary Layer EXperiment; CART, Cloud and Radiation Testbed; CASES, Cooperative Atmosphere-Surface Exchange Study; CLEX, Cloud Layer EXperiment; DIAL, DIfferential Absorption Lidar, DSIT, Data and Science Integration Team; EBBR, energy balance Bowen ratio; ECOR, eddy correlation; FDDA, four-dimensional data assimilation; GCIP, GEWEX Continental-Scale International Project; GEWEX, Global Energy and Water Cycle Experiment; GIST, GEWEX Integrated System Test; GPS, global positioning system; GRAMS, ground radiation measurement system; IDP, Instrument Development Program; IOP, intensive observation period; IR, infrared; IRF, instantaneous radiative flux; ISS, integrated sounding system; LLJ, Low-Level Jet; LMS, Lockheed Missile and Space; MSX, Midcourse Satellite Experiment; PBL, planetary boundary layer; RASS, radio acoustic sounding system; SCM, single-column model; SGP, Southern Great Plains; SITAC, Spectral Imagery Technology Applications Center; SUCCESS, Subsonic Aircraft: Contrail and Cloud Effects Special Study; TBD, to be determined; TWP, Tropical Western Pacific; UAV, unmanned aerospace vehicle; VORTEX, Verification of the Origins of Rotation in Tornadoes Experiment. 
The Summer 1997 Single-Column Model IOP. An SCM is a physical parameterization package extracted from a GCM or other large-scale model. The SCM is a primary test of our current understanding of clouds and radiative transfer. The SCM IOPs are designed to provide, as boundary conditions, the advective tendencies and vertical velocities that are the dynamic forcing normally calculated with a GCM. The BBSS is the only technology currently capable of providing the range and resolution of observations of winds and thermodynamic quantities necessary to estimate these boundary conditions. Because derivatives are needed in both horizontal directions, BBSS data from the central facility and the four boundary facilities are the minimum required for reliable estimates. Although this IOP has always taken place during mid-July through early August, it was rescheduled to coincide with the SGP '97 (Hydrology) IOP from June 18 to July $18,1997$.

The SGP '97 (Hydrology) IOP. This joint NASA/USDA effort is a hydrology and boundary layer experiment to map out soil moisture at satellite temporal and spatial scales in the SGP. The key remote sensing instrument during the SGP '97 (Hydrology) IOP will be the L-band electronically scanned thinned-array radiometer aboard a P-3 aircraft. An attempt will be made to carry out a daily soil moisture mapping of the SGP $(1,000-\mathrm{km} \times 1,000-\mathrm{km}$ area $)$ over a period of one month. Crucial to the project are the extensive in situ observing programs of the USDA Micronet, the Oklahoma Mesonet (OKM), and the U.S. Department of Energy (DOE) SGP CART site. In addition, data will be validated by a gravimetric sampling program. A boundary layer component was added, and a Twin Otter aircraft will provide for area-averaged fluxes within the boundary layer over the southwest section of the SGP CART site domain. This activity occurred June 18-July 18, 1997. Please contact Tom Jackson (USDA) for details at (202) 358-0771 or Ming-Ying Wei (NASA) at (202) 358-0771.

The Fall 1997 Integrated IOP. This IOP will occur approximately during the period of September 15 -October 3,1997 , primarily at the central facility, and will comprise six individual IOPs that have overlapping interests:

Single-Column Model IOP. This SCM IOP is identical to the summer SCM IOP but will occur during the fall season to coincide with the other components during fall 1997.

ARM UAVIOP. This continuation of an IOP series that began in April 1994 will include both the Altus unmanned aerospace vehicle (UAV) and the Twin Otter aircraft. The science focus of this IOP will mainly be on shortwave radiation and 
clear and cloudy absorption, but the UAV will support the other ongoing IOPs to the extent possible. Early plans call for the Altus to hover around $14-15 \mathrm{~km}$ in a butterfly pattern from sunrise to sunset with 8 -min legs, and for the Twin otter to serve as an escort and to perform stacked flights.

Water Vapor IOP. This IOP, the second in a series of three devoted to water vapor, will build upon the knowledge learned during the first such IOP in September 1996. It will continue the capabilities of the CART instruments for characterizing water vapor and will increase the emphasis on water vapor at higher levels (the first Water Vapor IOP primarily studied the lowest 1,000 m). This IOP will utilize the ARM UAV and aircraft along with an array of guest instrumentation.

Shortwave Radiation IOP. A shortwave radiation IOP series is being planned. The emphasis of this IOP would be on spectrally resolved and broadband measurements of the shortwave, especially the diffuse component. Emphasis will also be placed on instrument calibration, characterization, and intercomparison and on evaluation of the new GRAMS radiometers (formerly called Valero radiometers). One question to be addressed concerns whether or not there is enhanced shortwave absorption in clear and cloudy skies and, if so, how it is partitioned between the near IR and the visible. The first of a planned series of three IOPs has several goals: compare measurements of spectral fluxes from an array of spectrometers to assess our current ability to measure spectral fluxes; contrast spectral and broadband fluxes to determine the level of consistency between them; characterize measurements in terms of other parameters such as columnar water content and aerosol optical depth; and promote the development of a baseline-spectral solar transfer model and compare this model against measurements. This IOP will also heavily rely on the UAV and guest instrumentation.

Cloud IOP. This IOP (along with the Aerosol IOP) provides an unprecedented (for ARM) opportunity to quantify cloud and radiation interactions and will serve as a follow-up to the April 1997 Cloud Radar IOP. A main thrust will be to validate cloud property retrieval algorithms that use surface-based remote sensor and satellite measurements. A number of such algorithms will someday be applied to operational CART data streams, but the algorithms need validation, 
streamlining, and possible modification before such application can be done (thus the need for the IOP). The IOP should provide the requisite data to (1) ensure that the most accurate set of targeted algorithms will be implemented; (2) quantify the uncertainty associated with the retrieval of cloud properties from algorithms; (3) provide absolute calibration and intercalibration for MMCRs used for this type of cloud research; and (4) provide guidance on operational modes of the CART MMCR. This IOP will rely on the UAV, aircraft, and guest instrumentation. The aircraft proposed for this IOP is the Wyoming King Air.

Aerosol IOP. This IOP (along with the Cloud IOP) will serve as a follow-up to the April 1997 Cloud Radar IOP, in which data were collected to validate the new CART MMCR. The Aerosol IOP will (1) include a more thorough aerosol measurement program to support algorithm development for micropulse lidar (MPL) and Raman lidar profiles and to support basic research; (2) conduct in situ measurements for comparing lidar (thin cloud) and radar microphysical retrievals;

(3) conduct in situ measurements important to cloud radiative properties; and

(4) compare ARM UAV collections of upwelling radiation above the in situ measurement area with aircraft downwelling radiation below the clouds. As with the other Fall 1997 Integrated IOP components, this IOP will depend on UAV and aircraft flights and on the guest instrumentation at the surface.

The $\mathrm{CO}_{2}$ Differential Absorption Lidar IOP. John Jolin, Los Alamos National Laboratory (LANL), anticipates conducting a DOE-funded experiment at the SGP CART site. His experiment uses a $10-\mathrm{kHz}$ tunable-frequency lidar system for the 9- to $11-\mu \mathrm{m}$ wavelength region of interest. The $\mathrm{CO}_{2}$ DIfferential Absorption Lidar (DIAL) system can be mounted in aircraft or be ground-based. Currently, the aircraft system is being considered. The $\mathrm{CO}_{2}$ DIAL system will be used to identify trace chemical species, as well as to measure water vapor. The system on board a U.S. Air Force KC-135 aircraft can be used to make spectrally resolved albedo measurements. This IOP has been delayed until October 1998.

\subsection{Collaborative Investigations}

Argonne National Laboratory has developed a new research facility within the existing boundaries of the SGP CART site to be devoted to studies of the planetary boundary layer (PBL). The Argonne Boundary Layer Experiment (ABLE) cover an area approximately $50 \mathrm{~km} \times$ $50 \mathrm{~km}$ within the Walnut River watershed in Butler County, Kansas, about $50 \mathrm{~km}$ (30 mi) east of 
Wichita and near the Towanda extended facility. New techniques of observation and data fusion will be developed and used to study the nocturnal low-level wind maximum and its relation to the synoptic jet features; to develop methods for spatial integration of air-surface exchange of heat, gases, and momentum; and to study horizontal and vertical dispersion in the PBL. The initial set of instrumentation currently available at ABLE includes two $915-\mathrm{MHz}$ profilers with RASS, three minisodars, one surface ECOR flux station, one soil moisture and temperature station, three automated weather stations (AWSs), and one satellite data receiver processor. One central location will house data collection equipment and instrumentation and will provide accommodations for visiting scientists. The data obtained are being provided in real time to a user community of atmospheric scientists and ecologists.

The 915-MHz profilers with RASS and the minisodars have been installed at Oxford and Whitewater, Kansas. A minisodar and an AWS have been added to the ARM Program's Beaumont, Kansas, intermediate facility, which is shared by and provides data streams for both the ARM Program and ABLE. In addition, an extensive automated high-spatial-resolution soil moisture and temperature network will be installed and remain in place, located in the Towanda subbasin. A second network (not automated) with larger spacing may also remain in place. All are within the footprint of the Wichita next-generation radar (NEXRAD).

The Cooperative Atmosphere-Surface Exchange Study (CASES) is a collaborative effort to obtain measurements over the entire Walnut River watershed (approximately $100 \mathrm{~km} \times 100 \mathrm{~km})$ in and around Butler County, Kansas, about $50 \mathrm{~km}(30 \mathrm{mi})$ east of Wichita. The CASES initiative will obtain measurements over a somewhat larger domain than ABLE. CASES will include hydrologic, ecological, and atmospheric chemistry studies, in addition to ABLE research.

Several PIs have been funded as part of CASES to do boundary layer research over the CASES/ABLE domain. The principal contacts for CASES are Peggy LeMone, National Center for Atmospheric Research (NCAR), and Bob Grossman, University of Colorado. The CASES experiment period was April 22-May 19, 1997, and the types of investigations included the diurnal variation of the PBL for different surface evaporation conditions; validation of the ABLE profilers; surface flux measurements, including $\mathrm{CO}_{2}$ and $\mathrm{O}_{3}$; soil moisture measurements; validation of radar rainfall estimates; boundary layer flux measurements; low-level jet studies; etc. The types of instrumentation include eight surface flux stations and the air-surface turbulence exchange research (ASTER) system; the University of Wyoming King Air and NOAA Twin Otter $\mathrm{CO}_{2}$ and $\mathrm{O}_{3}$ flux instruments; a 35 tipping-bucket rain-gauge network and 
20 sites for manual time-domain refractometry to get soil moisture within the Wichita NEXRAD radar footprint; a 10-cm polarization radar; an all-sky camera; and three cross-chain loran atmospheric sounding systems (CLASSs).

\subsection{Geophysically Significant Phenomena}

The ARM Program has transitioned toward the GVFA, which focuses on the study of geophysically significant phenomena (e.g., water vapor profiles, aerosols, clouds, temperature profiles, and radiation). Algorithm development that describes these phenomena is a current primary focus.

The algorithm products represent a merging of appropriate instrument measurements into a cohesive product defining a particular geophysical state, for use by the Science Team. These products specifically address problems posed in the Science Plan and by various working groups. A product example currently under construction is one prescribing water vapor over the SGP CART site sought by the IRF Working Group. As noted above, such an effort involves three IOPs obtaining multiple water vapor measurements at the central facility (e.g., additional measurements on the 60-m tower; use of a tethersonde system; use of guest instruments and additional instruments, such as chilled mirrors and frost-point hygrometers) and comparison of these measurements with routine BBSS, Raman lidar, MWR, and 915- and 50-MHz RASS water vapor profiles. The end result of such comparisons will be the generation of an ensemble, siterepresentative water vapor profile for use in GCMs.

\subsection{Educational Outreach}

The educational outreach program for the SGP CART site, coordinated by Dr. Ken Crawford, Director of the Oklahoma Climatological Survey (OCS), combines a range of resources available at OU. Outreach efforts are focused at the precollege, undergraduate, and graduate levels. Efforts in this six-month period will be focused on continuing the integration of ARM and NWS data (as nearly in real time as possible) into the EARTHSTORM project, a program conducted by the OCS to integrate real-time data into classroom activities in kindergarten through grade 12 (McPherson and Crawford 1996). The EARTHSTORM project currently accesses data from the OKM, a high-density network of surface meteorological stations, and provides the data to students in real time. EARTHSTORM has created learning modules and has provided teacher workshops to enhance the use of OKM data. Extension of these activities to include SGP ARM data is now beginning to occur at a significant level. In 
addition, an ARM/Kansas teachers' workshop will take place at OU in July 1997. Further extension of these efforts to the Tropical Western Pacific and North Slope of Alaska ARM sites will be investigated. 


\section{DISTRIBUTION OF DATA}

Most of the data being requested are received from the SGP CART site or external data sources and are then repackaged for daily and weekly distribution to individual users. In some cases, users can log into the Experiment Center or the R1 System at the central facility and extract data by anonymous file transfer protocol (FTP). All data are sent to the Data Archive, where they are accessible to anyone at the WWW site:

http://www.archive.arm.gov .

The current status of CART and external data streams can be accessed at the uniform resource locators (URLs) provided in Sections 3.4 and 3.5.2 of this report.

The status of data streams from CART instruments or external sources has been classified as releasable (released upon request for the data stream), developmental (released only to SDS personnel for development of ingestion programs), under evaluation (released to an investigator for an initial data quality check), beta release (for releasable data of known and reasonable quality), collecting (when raw data are being collected for future processing and distribution), mentor only (when the data stream is provided only to the instrument mentor at the request of the mentor), analysis (if the data stream is released for further processing and/or analysis, such as for graphic display), or defunct (due to replacement of a prototype instrument data stream with the CART instrument data stream). 


\section{LOOKING AHEAD}

The essentially fully mature SGP CART site now provides the full range of data streams needed to support the DSIT's "building block" algorithm development effort and a broad spectrum of Science Team research. These activities, in turn, are increasingly drawing on multiple SGP data streams to focus strongly on geophysically significant phenomena (water vapor profiles, clouds, aerosols, temperature profiles, radiation, surface fluxes). The operational challenges that will be of greatest importance during 1998 and beyond will therefore include maintaining the performance of the basic instrumentation suite at the highest possible level, improving that performance where possible, enhancing the original CART design through the permanent addition of new instruments, and mounting focused IOPs involving temporary additional instrumentation. Through this mix of activities, the evolving scientific requirements, challenges, and opportunities for the SGP CART will be met. The present chapter outlines the path ahead, to the extent that it can be identified in mid-1997.

The key developments that are expected to occur at the central facility during the present six-month period and the following 18 months include the achievement of the routine, unattended, continuous operation of the Raman lidar; use of the recently completed RCF; upgrading of the Vaisala BBSS sondes (see below); and the installation of several new instruments (CSPHOT, TLCV, UV-B sensor, PAR, optical transmissometer, GRAMS, and a solar spectral radiometer). The solar spectral radiometer will provide solar spectral observations at the central facility that are needed for the testing and improving of solar radiation models. A narrow-field-of-view zenith sky radiance sensor in the near IR has also been suggested for that location. The sensor would have the advantage of a field of view that overlaps or nearly coincides with that of the MWR and possibly MMCR. Another central facility measurement issue now under consideration includes the possibility of acquiring continuous direct-beam solar irradiance measurements with a cavity radiometer.

The utility of the Raman lidar to characterize the lower half of the troposphere (e.g., water vapor, clouds, aerosols) more accurately and with a finer vertical resolution than is possible with the original suite of instruments (BBSSs, MWRs) has been strongly advocated by the IRF Working Group. The routine, unattended, continuous operation of the Raman lidar remains an ongoing goal, following the installation in spring 1997 of a permanent hail shield. The operation of the Raman lidar and its measurements strategy are being closely monitored for improvements. Also, the recent installation of the MMCR is already enhancing the algorithm development efforts of the VAP Working Group to improve the definition of cloud 
characteristics (fractional coverage, as well as base and top heights) above the central facility, in coordination with key Science Team members. The MMCR is equipped to map the vertical extent of cloud boundaries up to a height of approximately $20 \mathrm{~km}$. Coincident measurements of vertical wind speed will be obtained from Doppler analysis. The system will operate only in the vertically pointing position.

Improved specifications of the water vapor, temperature, and cloud conditions above the boundary facilities are expected to result from several observational enhancements and additions during 1997 and 1998. First, the addition of ceilometers is primarily intended to provide data for algorithms that will retrieve lower tropospheric temperature and humidity profiles from the output of new, planned AERI instruments. Second, higher quality BBSS soundings should result from a planned upgrade of the Vaisala sensors being used (from RS-80 to RS-90). The RS-90 humidity sensor has a faster response time and thus recovers more quickly than its predecessor after emerging from clouds. Its temperature counterpart is also smaller and has a faster response time than the RS-80 and, in addition, is less susceptible to solar heating. An identical BBSS upgrade will occur at the central facility. Under consideration for the boundary facilities is a capability to profile with passive microwave systems, which would augment the AERI measurements.

By the end of 1997, with the completion of extended facilities at Seminole (over pasture) and El Reno (pasture) and at a wooded Okmulgee site, the basis for the spatial integration of the turbulent and radiative fluxes over the entire SGP CART site will have been firmly established through the completion (according to their original design) and upgrading of all 23 extended facilities. A key feature of that upgrading is the present near completion of SWATS at all extended facilities. The SWATS data will contribute significantly to completing the characterization of the land surface and subsurface that is essential for investigating surface heat and moisture exchanges. In a closely related development, approximately 40 additional identical SWATSs are being installed at OKM sites within the SGP CART site domain during a two-year period that began in mid-1996. The SWATSs that existed in midsummer 1997 (approximately 40) were the centerpiece of an ARM/USDA/NASA Hydrology IOP conducted in June and July 1997, which also made use of satellite and aircraft data and focused in particular on soil moisture. The second half of 1997 should see the completion of improved SIROS data logging at the central and extended facilities. This improvement is involving both (1) the introduction of independent data logging systems for the SIROS broadband sensors, which will henceforth be known as SIRS (solar and infrared station), and (2) the MFRSRs becoming the sole users of the original systems that were previously shared with the SIROS instrument suites. Improved 
reliability of the SIROS/SIRS data gathering should result. A similar logging system subsequently will be introduced for the BSRN (to be renamed BRS [broadband radiometer station]). Measurement issues under consideration at the extended facilities include local observations of surface vegetative conditions and measurements of surface bidirectional reflectance.

The capability for monitoring land-atmosphere interactions recently was enhanced further with the establishment and operation of three ARM intermediate facilities containing $915-\mathrm{MHz}$ profilers with RASS, which are being used to quantify structures and processes in the PBL. Stabilization of these systems will occur during the rest of 1997, and significant scientific dividends will begin to accrue in late 1997 and 1998.

Perhaps the largest of all ARM IOPs planned and conducted to date will occur during mid-September to early October of the present six-month period. This IOP will not only include the originally planned second Water Vapor IOP, SCM IOP, and UAV IOP, but also IOPs concentrating on shortwave radiation, clouds, and aerosols. The six IOPs are collectively being called the Fall 1997 Integrated IOP. The Water Vapor IOP will use knowledge learned from its September 1996 forerunner to guide its operations, which will include a higher-altitude focus on water vapor distributions. The Shortwave Radiation IOP will focus on both spectrally resolved and broadband instrumentation assessments and intercomparisons. The Cloud and Aerosol IOPs will concentrate on in situ measurements in clear and cloudy sky conditions, to validate cloud property algorithms and compare microphysical retrievals. The UAV IOP aims to focus on radiation and support the efforts of all of the other IOPs, and the SCM IOP should have strong synergy with the Cloud and Aerosol IOPs, because the in situ measurements of cloud and aerosol properties are valuable for assessment of SCM parameterizations. A coordination meeting for all of these IOPs is scheduled to occur in July 1997. Key planning issues include maximizing the mutual benefits between IOPs while minimizing the inevitable conflicts. Careful logistical planning will be required for designing the timing and location of airborne IOP resources and for locating ground-based instruments at the central facility. Most of the analysis of the data obtained will occur in 1998, which, in turn, may lead to follow-up IOPs. Certainly, further water vapor, shortwave, and SCM IOPs are already planned for 1998.

The SGP CART site activities during 1998 will continue to capitalize on the 1996 installation of the aerosol instrumentation and the RCF at the central facility. The data from the aerosol instruments are filling a significant gap in the specification of the radiative state of the near-surface atmosphere. Indeed, the importance for ARM of aerosol effects is likely to grow in 
the next two years. The establishment of the RCF is a key element in the total quality control effort addressing the wide variety of radiometers at the central facility and the more limited SIROS/SIRS radiometer suites at the extended facilities. Establishment of the RCF was accomplished during the latter half of 1996 and will be augmented by the development and implementation of a comprehensive integrated RCF Operations Plan as the SGP CART site moves from the establishment of routine operations to the maintenance of routine operations, with inherent instrument-aging problems. BORCALs are planned for summer 1997.

The SST will continue to assist in the calibration and maintenance areas during late 1997-1998, when it will also contribute further to the quality control and assurance of the ever-expanding SGP CART data bank through the further development and use of graphic data quality display modules and performance metrics. As noted in earlier chapters, the graphic displays, which plot actual data against modeled expectations, are intended for use by site operations staff (and the SST) to aid in their efforts to perform "first-line-of-defense" near-real-time quality assurance relative to instrument operation. The performance metrics are intended to give a broader view of instrument performance and data quality over the CART site relative to how data fall within or outside of specified quality tolerances, such as range and consistency checks, and already include platform intercomparisons. Both efforts represent a major step forward toward achieving a comprehensive end-to-end quality control system for instrument performance and data. Further in that regard, in spring 1997, the SST began issuing weekly data quality assessments, using input from other groups within ARM as well as its own assessment tools.

During 1998, the SGP CART site observational capabilities are expected to continue to benefit from ongoing interactions between the ARM Program and several other federal and state research programs having an interest in the SGP in general. The federal agency interactions, which until now have particularly involved the GCIP component of GEWEX, are currently being broadened through the leadership of NASA and the USDA in the aforementioned midsummer 1997 Hydrology IOP. These interactions are also currently manifest in the approximately biannual meeting of a joint ARM-GCIP-ISLSCP Working Group (on which ARM is represented by J.C. Doran, R.G. Ellingson, and P.J. Lamb); the aforementioned implementation of the SWATS at the ARM extended facilities, with significant financial support from GCIP; and the USDA's facilitation and partial funding of the above El Reno extended facility. The Joint Working Group will be concerned not only with fostering the most cost-effective and efficient observational strategies for the SGP CART site for 1998 and subsequent years, but also with formulating the best possible scientific use of the resulting data among their programs. 
Consistent with this latter goal, the Working Group's May 1997 meeting focused on "ValueAdded Science," which will likely be a continuing theme of that forum. Interactions with the OKM, which has been an important source of external data for the SGP for several years, are expected to increase with the OKM's aforementioned parallel deployment of approximately 40 SWATSs. Finally, a joint effort between the NWS and ARM has now resulted in ARM radiosonde data being made available to the meteorological community at large via the Global Telecommunications System. This availability will be especially valuable for the NWS shortrange prediction efforts during the tornado seasons of the next few years.

The integration of ARM UAV operations into the SGP CART site scientific mission was initiated successfully during the April 1994 IOP, which used a small UAV (GNAT) that could ascend only to $6.7 \mathrm{~km}$ (about 22,000 ft). However, delays in developing, testing, and gaining operational approval for the larger UAVs needed for radiation measurements at higher elevations precluded their subsequent use over the SGP CART site for the next two years. Manned aircraft were used instead, as during the ARESE IOP. Fortunately, this situation was rectified with the deployment of the Altus UAV during the September 1996 Water Vapor IOP, which permitted the valuable operation of highly stable UAV-mounted radiation and other instruments over the SGP CART site. Indeed, this operation constituted a great step forward for the use of UAVs in scientific research in general, because it included a record-breaking 26-hour mission. The use of UAVs is therefore expected to be an essential ingredient of planned and future IOPs, such as the Fall 1997 Integrated IOP and its 1998 follow-ups. All UAV operations will continue to be supported by climatological analyses by the SST of historical cloud and wind data for the SGP vicinity.

Throughout 1998, the scientific operation of the SGP CART site should benefit significantly from guidance provided by the SAC. The fundamental role of the SAC is to ensure that the operation of the site addresses the goals and objectives of the ARM Program (published in the 1996 Science Plan) to the fullest possible extent, including through successful adaptation to changing circumstances and opportunities. Such performance will ensure that the flows of data to the Science Team members are appropriate to their needs, of consistently high quality, and as continuous as possible. For example, the recent redoubling of efforts by the SST to help ensure the quality of SGP data is consistent with the strong encouragement offered by the November 1995 SAC Review. Because the membership of the SAC is divided approximately equally between ARM Science Team members and nonmembers, its guidance reflects both the inherently more parochial concerns of the ARM Science Team and the broader global-change perspective of the others. The recommendations from the November 1995 and June 1996 SAC 
meetings are now being acted upon by the SST and will be reflected in the scientific capability of the site during 1998 and beyond. Those recommendations included the aforementioned need for increased attention to quality assurance and quality control of the SGP instruments and data streams, the necessity of making midcourse corrections (including those of personnel assignments and funding priorities) to ensure that the configuration and operation of the SGP CART site are in full consonance with the ARM Science Plan priorities, the desirability of converting the Site Scientific Mission Plan into an article for publication in the Bulletin of the American Meteorological Society that would publicize the scientific potential of the site (to be completed during the present six-month period); and the inauguration of an SST "Visitor Program" that would particularly involve cloud and radiation data analyses and simulations with the goal of enhancing the site's observational capabilities in those crucial areas. Thus, from now onward, the SAC guidance will have a continuing effect on the scientific mission of the SGP CART site. This fact, coupled with the recent maturation of the site, should result in optimal operation of this ARM locale with respect to the goals and objectives of the overall ARM Program during 1998 and subsequent years. A further SAC review is scheduled for fall 1997. 


\section{REFERENCES}

McPherson, R.A., and K.C. Crawford, 1996, "The EARTHSTORM Project: Encouraging the Use of Real-Time Data from the Oklahoma Mesonet in K-12 Classrooms," Bulletin of the American Meteorological Society 77:749-761.

Schneider, J.M., P.J. Lamb, and D.L. Sisterson, 1993, Site Scientific Mission Plan for the Southern Great Plains CART Site: January-June 1994, ARM-94-001, Argonne National Laboratory, Argonne, Illinois.

U.S. Department of Energy, 1990, ARM Program Plan, 1990, DOE/ER-0441, Washington, D.C.

U.S. Department of Energy, 1996, Science Plan for the Atmospheric Radiation Measurement Program, DOE/ER-0670T, Washington, D.C. 
APPENDIX:

STATUS AND LOCATIONS OF INSTRUMENTS 
TABLE A.1 Actual and Planned Locations of Instruments at the Central Facilitya

\begin{tabular}{|c|c|c|c|c|}
\hline Instrument & $\begin{array}{c}\text { Latitude, } \\
\text { Longitude } \\
\text { (deg) }\end{array}$ & Surface Type & Location & Comments \\
\hline AERI & $\begin{array}{l}36.967 \mathrm{~N} \\
97.528 \mathrm{~W}\end{array}$ & Pasture & Optical trailer & - \\
\hline AERI $X$ & $\begin{array}{l}36.967 \mathrm{~N} \\
97.528 \mathrm{~W}\end{array}$ & Pasture & Optical trailer & - \\
\hline SORTI & $\begin{array}{l}36.967 \mathrm{~N} \\
97.528 \mathrm{~W}\end{array}$ & Pasture & Optical trailer & - \\
\hline BSRN & $\begin{array}{l}36.993 \mathrm{~N} \\
97.708 \mathrm{~W}\end{array}$ & Pasture & Central cluster & - \\
\hline BRS & $\begin{array}{l}36.993 \mathrm{~N} \\
97.708 \mathrm{~W}\end{array}$ & Pasture & Central cluster & - \\
\hline SIROS & $\begin{array}{l}36.993 \mathrm{~N} \\
97.708 \mathrm{~W}\end{array}$ & Pasture & Central cluster & - \\
\hline SIRS & $\begin{array}{l}36.993 \mathrm{~N} \\
97.708 \mathrm{~W}\end{array}$ & Pasture & Central cluster & - \\
\hline UV-A & - & Pasture & Central cluster & Not installed \\
\hline UV-B & - & Pasture & Central cluster & Not installed \\
\hline PAR & - & Pasture & Central cluster & Not installed \\
\hline 10-m MFR & $\begin{array}{l}36.785 \mathrm{~N} \\
97.665 \mathrm{~W}\end{array}$ & Pasture & Central cluster & - \\
\hline 25-m USR & $\begin{array}{l}36.932 \mathrm{~N} \\
97.916 \mathrm{~W}\end{array}$ & Wheat & $60-\mathrm{m}$ tower & - \\
\hline 25-m UIR & $\begin{array}{l}36.932 \mathrm{~N} \\
97.916 \mathrm{~W}\end{array}$ & Wheat & $60-\mathrm{m}$ tower & - \\
\hline 25-m MFR & $\begin{array}{l}36.932 \mathrm{~N} \\
97.916 \mathrm{~W}\end{array}$ & Wheat & 60-m tower & - \\
\hline CSPHOT & - & Pasture & Optical trailer & Not installed \\
\hline BBSS & $\begin{array}{l}37.012 \mathrm{~N} \\
98.120 \mathrm{~W}\end{array}$ & Grass & Central compound & - \\
\hline
\end{tabular}


TABLE A.1 (Cont.)

\begin{tabular}{|c|c|c|c|c|}
\hline Instrument & $\begin{array}{l}\text { Latitude, } \\
\text { Longitude } \\
\text { (deg) }\end{array}$ & Surface Type & Location & Comments \\
\hline $\begin{array}{l}\text { 915-MHz } \\
\text { RWP }\end{array}$ & $\begin{array}{l}36.677 \mathrm{~N} \\
97.686 \mathrm{~W}\end{array}$ & $\begin{array}{l}\text { Shale, } \\
\text { pasture }\end{array}$ & Profiler trailer & - \\
\hline $\begin{array}{l}\text { 50-MHz } \\
\text { RWP }\end{array}$ & $\begin{array}{l}36.630 \mathrm{~N} \\
97.706 \mathrm{~W}\end{array}$ & $\begin{array}{l}\text { Shale, } \\
\text { pasture }\end{array}$ & Profiler trailer & - \\
\hline MWR & $\begin{array}{l}37.105 \mathrm{~N} \\
97.765 \mathrm{~W}\end{array}$ & Pasture & Optical trailer & - \\
\hline RLID & $\begin{array}{l}38.052 \mathrm{~N} \\
97.741 \mathrm{~W}\end{array}$ & $\begin{array}{l}\text { Pasture, } \\
\text { wheat }\end{array}$ & IDP 3 & - \\
\hline WSI & $\begin{array}{l}36.842 \mathrm{~N} \\
97.608 \mathrm{~W}\end{array}$ & Pasture & Optical trailer & - \\
\hline BLC & $\begin{array}{l}36.697 \mathrm{~N} \\
97.528 \mathrm{~W}\end{array}$ & Pasture & Optical trailer & - \\
\hline MPL & $\begin{array}{l}36.967 \mathrm{~N} \\
97.528 \mathrm{~W}\end{array}$ & Pasture & Optical trailer & - \\
\hline MMCR & $\begin{array}{l}36.885 \mathrm{~N} \\
97.591 \mathrm{~W}\end{array}$ & $\begin{array}{l}\text { Pasture, } \\
\text { wheat }\end{array}$ & IDP 2 & - \\
\hline TLCV & - & Pasture & $\begin{array}{l}\text { Optical trailer } \\
\text { cluster }\end{array}$ & Not installed \\
\hline $25-\mathrm{m} \mathrm{T} / \mathrm{RH}$ & $\begin{array}{l}36.932 \mathrm{~N} \\
97.916 \mathrm{~W}\end{array}$ & Wheat & $60-\mathrm{m}$ tower & - \\
\hline $60-\mathrm{m} \mathrm{T} / \mathrm{RH}$ & $\begin{array}{l}36.932 \mathrm{~N} \\
97.916 \mathrm{~W}\end{array}$ & Wheat & $60-\mathrm{m}$ tower & - \\
\hline ECOR & $\begin{array}{l}36.857 \mathrm{~N} \\
97.631 \mathrm{~W}\end{array}$ & $\begin{array}{l}\text { Wheat, } \\
\text { pasture }\end{array}$ & Aerosol trailer & - \\
\hline 25-m ECOR & $\begin{array}{l}36.932 \mathrm{~N} \\
97.916 \mathrm{~W}\end{array}$ & Wheat & $60-\mathrm{m}$ tower & - \\
\hline 60-m ECOR & $\begin{array}{l}36.932 \mathrm{~N} \\
97.916 \mathrm{~W}\end{array}$ & Wheat & 60 -m tower & - \\
\hline EBBR & $\begin{array}{l}36.887 \mathrm{~N} \\
97.531 \mathrm{~W}\end{array}$ & Pasture & Central cluster & - \\
\hline
\end{tabular}


TABLE A.1 (Cont.)

\begin{tabular}{|c|c|c|c|c|}
\hline Instrument & $\begin{array}{l}\text { Latitude, } \\
\text { Longitude } \\
\text { (deg) }\end{array}$ & Surface Type & Location & Comments \\
\hline SMOS & $\begin{array}{l}36.785 \mathrm{~N} \\
97.665 \mathrm{~W}\end{array}$ & Pasture & Central cluster & - \\
\hline AOS & $\begin{array}{l}36.927 \mathrm{~N} \\
97.828 \mathrm{~W}\end{array}$ & $\begin{array}{l}\text { Pasture, } \\
\text { wheat }\end{array}$ & Aerosol trailer & - \\
\hline $\mathrm{RCF}$ & $\begin{array}{l}36.958 \mathrm{~N} \\
97.653 \mathrm{~W}\end{array}$ & $\begin{array}{l}\text { Pasture, } \\
\text { wheat }\end{array}$ & Calibration trailer & - \\
\hline RSS & - & Pasture & $\begin{array}{l}\text { Optical trailer } \\
\text { cluster }\end{array}$ & Not installed \\
\hline SWS & - & Pasture & Optical trailer & Not installed \\
\hline GRAMS & - & Pasture & $\begin{array}{l}\text { Optical trailer } \\
\text { cluster }\end{array}$ & Not installed \\
\hline
\end{tabular}

a AERI, atmospherically emitted radiance interferometer; AOS, aerosol observation system; BBSS, balloon-borne sounding system; BLC, Belfort laser ceilometer; BRS, broadband radiometer station; BSRN, Baseline Surface Radiation Network; CSPHOT, Cimel sunphotometer; EBBR, energy balance Bowen ratio; ECOR, eddy correlation; GRAMS, ground radiation measurement system; IDP, Instrument Development Program; MFR, multifilter radiometer; MMCR, millimeter cloud radar; MPL, micropulse lidar; MWR, microwave radiometer; PAR, photosynthetically active radiometer; RCF, radiometer calibration facility; RLID, Raman lidar; RSS, rotating shadowband spectrometer; RWP, radar wind profiler; SIROS, solar and infrared radiation observing system; SIRS, solar and infrared station; SMOS, surface meteorological observation station; SORTI, solar radiance transmission interferometer; SWS, shortwave spectrometer; TLCV, time-lapse cloud video; T/RH, temperature and relative humidity sensor; UIR, upwelling infrared radiometer; USR, upwelling solar radiometer; UV-A, ultraviolet A; UV-B, ultraviolet B; Vceil, Vaisala ceilometer; WSI, whole-sky imager. 
TABLE A.2 Locations and Status of Extended Facilities ${ }^{\text {a }}$

\begin{tabular}{|c|c|c|c|c|c|c|c|c|c|}
\hline Site & $\begin{array}{l}\text { Elevation } b \\
\quad(\mathrm{~m})\end{array}$ & $\begin{array}{l}\text { Latitude, } \\
\text { Longitude } \\
\text { (deg) }\end{array}$ & $\begin{array}{l}\text { Surface } \\
\text { Type }\end{array}$ & $\begin{array}{l}\text { Flux } \\
\text { Station }\end{array}$ & SWATSc & SMOS $^{\mathrm{c}}$ & $\begin{array}{l}\text { SIROS/ } \\
\text { SIRSc }\end{array}$ & Comment & \\
\hline $\begin{array}{l}\text { Larned, KS } \\
\text { EF-1 }\end{array}$ & 632 & $\begin{array}{l}38.202 \mathrm{~N} \\
99.316 \mathrm{~W}\end{array}$ & Wheat & $\begin{array}{l}\text { ECOR } \\
9 / 1 / 95\end{array}$ & $\begin{array}{l}\text { Yes } \\
6 / 96\end{array}$ & $\begin{array}{l}\text { Yes } \\
9 / 1 / 95\end{array}$ & $\begin{array}{l}\text { Yes } \\
9 / 1 / 95\end{array}$ & $\begin{array}{l}\text { Power and communication } \\
\text { center installed } 10 / 95\end{array}$ & \\
\hline $\begin{array}{l}\text { Hillsboro, } \mathrm{KS} \\
\text { EF-2 }\end{array}$ & 450 & $\begin{array}{l}38.306 \mathrm{~N} \\
97.301 \mathrm{~W}\end{array}$ & Pasture & $\begin{array}{l}\text { EBBR } \\
10 / 96\end{array}$ & $\begin{array}{l}\text { Yes } \\
6 / 96\end{array}$ & No & $\begin{array}{l}\text { Yes } \\
9 / 7 / 95\end{array}$ & $\begin{array}{l}\text { Power and communication } \\
\text { center installed } 8 / 95\end{array}$ & \\
\hline $\begin{array}{l}\text { LeRoy, KS } \\
\text { EF-3 }\end{array}$ & 338 & $\begin{array}{l}38.201 \mathrm{~N} \\
95.597 \mathrm{~W}\end{array}$ & $\begin{array}{l}\text { Wheat and } \\
\text { soybeans } \\
\text { (rotated) }\end{array}$ & $\begin{array}{l}\text { ECOR } \\
12 / 7 / 95\end{array}$ & $\begin{array}{l}\text { Yes } \\
9 / 96\end{array}$ & $\begin{array}{l}\text { Yes } \\
12 / 7 / 95\end{array}$ & $\begin{array}{l}\text { Yes } \\
12 / 7 / 95\end{array}$ & $\begin{array}{l}\text { Power and communication } \\
\text { center installed } 9 / 95\end{array}$ & \\
\hline $\begin{array}{l}\text { Plevna, KS } \\
\text { EF-4 }\end{array}$ & 513 & $\begin{array}{l}37.953 \mathrm{~N} \\
98.329 \mathrm{~W}\end{array}$ & $\begin{array}{l}\text { Rangeland } \\
\text { (ungrazed) }\end{array}$ & $\begin{array}{l}\text { EBBR } \\
4 / 3 / 93\end{array}$ & $\begin{array}{l}\text { Yes } \\
3 / 5 / 96\end{array}$ & $\begin{array}{l}\text { Yes } \\
3 / 28 / 95\end{array}$ & $\begin{array}{l}\text { Yes } \\
3 / 28 / 95\end{array}$ & $\begin{array}{l}\text { Power and communication } \\
\text { center installed } 3 / 95\end{array}$ & $\infty$ \\
\hline $\begin{array}{l}\text { Halstead, KS } \\
\text { EF-5 }\end{array}$ & 440 & $\begin{array}{l}38.114 \mathrm{~N} \\
97.513 \mathrm{~W}\end{array}$ & Wheat & $\begin{array}{l}\text { ECOR } \\
1997\end{array}$ & $\begin{array}{l}\text { Yes } \\
9 / 96\end{array}$ & $\begin{array}{l}\text { Yes } \\
5 / 31 / 96\end{array}$ & $\begin{array}{l}\text { Yes; } \\
\text { broad- } \\
\text { band } \\
\text { only } \\
5 / 31 / 96\end{array}$ & $\begin{array}{l}\text { Power and communication } \\
\text { center installed } 11 / 95\end{array}$ & \\
\hline $\begin{array}{l}\text { Towanda, KS } \\
\text { EF-6 }\end{array}$ & 409 & $\begin{array}{l}37.842 \mathrm{~N} \\
97.020 \mathrm{~W}\end{array}$ & Alfalfa & $\begin{array}{l}\text { ECOR } \\
12 / 14 / 95\end{array}$ & $\begin{array}{l}\text { Yes } \\
9 / 96\end{array}$ & $\begin{array}{l}\text { Yes } \\
12 / 14 / 95\end{array}$ & $\begin{array}{l}\text { Yes } \\
12 / 14 / 95\end{array}$ & $\begin{array}{l}\text { Power and communication } \\
\text { center installed } 8 / 95\end{array}$ & \\
\hline $\begin{array}{l}\text { Elk Falls, KS } \\
\text { EF-7 }\end{array}$ & 283 & $\begin{array}{l}37.383 \mathrm{~N} \\
96.180 \mathrm{~W}\end{array}$ & Pasture & $\begin{array}{l}\text { EBBR } \\
8 / 29 / 93\end{array}$ & $\begin{array}{l}\text { Yes } \\
3 / 12 / 96\end{array}$ & $\begin{array}{l}\text { Yes } \\
3 / 9 / 95\end{array}$ & $\begin{array}{l}\text { Yes } \\
3 / 9 / 95\end{array}$ & $\begin{array}{l}\text { Power and communication } \\
\text { center installed } 2 / 95\end{array}$ & \\
\hline $\begin{array}{l}\text { Coldwater, } \\
\text { KS } \\
\text { EF-8 }\end{array}$ & 664 & $\begin{array}{l}37.333 \mathrm{~N} \\
99.309 \mathrm{~W}\end{array}$ & $\begin{array}{l}\text { Rangeland } \\
\text { (grazed) }\end{array}$ & $\begin{array}{l}\text { EBBR } \\
12 / 8 / 92\end{array}$ & $\begin{array}{l}\text { Yes } \\
6 / 96\end{array}$ & $\begin{array}{l}\text { Yes } \\
3 / 4 / 93\end{array}$ & $\begin{array}{l}\text { Yes } \\
5 / 9 / 95\end{array}$ & $\begin{array}{l}\text { Power and communication } \\
\text { center installed } 5 / 95\end{array}$ & \\
\hline
\end{tabular}


TABLE A.2 (Cont.)

\begin{tabular}{|c|c|c|c|c|c|c|c|c|}
\hline Site & $\begin{array}{l}\text { Elevation } \mathrm{b} \\
(\mathrm{m})\end{array}$ & $\begin{array}{l}\text { Latitude, } \\
\text { Longitude } \\
\text { (deg) }\end{array}$ & $\begin{array}{l}\text { Surface } \\
\text { Type }\end{array}$ & $\begin{array}{l}\text { Flux } \\
\text { Stationc }\end{array}$ & SWATSC & $\mathrm{SMOS}^{\mathrm{c}}$ & $\begin{array}{l}\text { SIROS/ } \\
\text { SIRSc }\end{array}$ & Comment \\
\hline $\begin{array}{l}\text { Ashton, KS } \\
\text { EF-9 }\end{array}$ & 386 & $\begin{array}{l}37.133 \mathrm{~N} \\
97.266 \mathrm{~W}\end{array}$ & Pasture & $\begin{array}{l}\text { EBBR } \\
12 / 10 / 92\end{array}$ & $\begin{array}{l}\text { Yes } \\
2 / 27 / 96\end{array}$ & $\begin{array}{l}\text { Yes } \\
3 / 13 / 90\end{array}$ & $\begin{array}{l}\text { Yes } \\
10 / 5 / 93\end{array}$ & $\begin{array}{l}\text { Power and communication } \\
\text { center installed } 10 / 93\end{array}$ \\
\hline $\begin{array}{l}\text { Tyro, KS } \\
\text { EF-10 }\end{array}$ & 248 & $\begin{array}{l}37.068 \mathrm{~N} \\
95.788 \mathrm{~W}\end{array}$ & Wheat & $\begin{array}{l}\text { ECOR } \\
7 / 21 / 95\end{array}$ & $\begin{array}{l}\text { Yes } \\
7 / 96\end{array}$ & No & $\begin{array}{l}\text { Yes } \\
7 / 21 / 95\end{array}$ & $\begin{array}{l}\text { Power and communication } \\
\text { center installed } 6 / 95\end{array}$ \\
\hline $\begin{array}{l}\text { Byron, OK } \\
\text { EF-11 }\end{array}$ & 360 & $\begin{array}{l}36.881 \mathrm{~N} \\
98.285 \mathrm{~W}\end{array}$ & Alfalfa & $\begin{array}{l}\text { ECOR } \\
6 / 26 / 95\end{array}$ & $\begin{array}{l}\text { Yes } \\
6 / 96\end{array}$ & $\begin{array}{l}\text { Yes } \\
6 / 26 / 95\end{array}$ & $\begin{array}{l}\text { Yes } \\
6 / 26 / 95\end{array}$ & $\begin{array}{l}\text { Power and communication } \\
\text { center installed } 6 / 95\end{array}$ \\
\hline $\begin{array}{l}\text { Pawhuska, } \\
\text { OK } \\
\text { EF-12 }\end{array}$ & 331 & $\begin{array}{l}36.841 \mathrm{~N} \\
96.427 \mathrm{~W}\end{array}$ & $\begin{array}{l}\text { Native } \\
\text { prairie }\end{array}$ & $\begin{array}{l}\text { EBBR } \\
8 / 29 / 93\end{array}$ & $\begin{array}{l}\text { Yes } \\
9 / 97\end{array}$ & No & $\begin{array}{l}\text { Yes } \\
6 / 30 / 95\end{array}$ & $\begin{array}{l}\text { Power and communication } \\
\text { center installed } 6 / 95\end{array}$ \\
\hline $\begin{array}{l}\text { Lamont, OK } \\
\text { EF-13, } 14\end{array}$ & 318 & $\begin{array}{l}36.605 \mathrm{~N} \\
97.485 \mathrm{~W}\end{array}$ & $\begin{array}{l}\text { Pasture, } \\
\text { wheat }\end{array}$ & $\begin{array}{l}\text { EBBR } \\
9 / 14 / 92 \\
\text { ECOR } \\
5 / 30 / 95\end{array}$ & $\begin{array}{l}\text { Yes } \\
2 / 5 / 96\end{array}$ & $\begin{array}{l}\text { Yes } \\
4 / 9 / 93\end{array}$ & $\begin{array}{l}\text { Yes } \\
10 / 15 / 93 \\
\text { BSRN } \\
5 / 15 / 92\end{array}$ & $\begin{array}{l}\text { Power and communication } \\
\text { center installed } 6 / 93\end{array}$ \\
\hline $\begin{array}{l}\text { Ringwood, } \\
\text { OK } \\
\text { EF-15 }\end{array}$ & 418 & $\begin{array}{l}36.431 \mathrm{~N} \\
98.284 \mathrm{~W}\end{array}$ & Pasture & $\begin{array}{l}\text { EBBR } \\
9 / 16 / 92\end{array}$ & $\begin{array}{l}\text { Yes } \\
2 / 21 / 96\end{array}$ & $\begin{array}{l}\text { Yes } \\
3 / 29 / 93\end{array}$ & $\begin{array}{l}\text { Yes } \\
10 / 12 / 93\end{array}$ & $\begin{array}{l}\text { Power and communication } \\
\text { center installed } 10 / 93\end{array}$ \\
\hline $\begin{array}{l}\text { Vici, OK } \\
\text { EF-16 }\end{array}$ & 602 & $\begin{array}{l}36.061 \mathrm{~N} \\
99.134 \mathrm{~W}\end{array}$ & Wheat & $\begin{array}{l}\text { ECOR } \\
5 / 30 / 95\end{array}$ & $\begin{array}{l}\text { Yes } \\
7 / 96\end{array}$ & No & $\begin{array}{l}\text { Yes } \\
5 / 30 / 95\end{array}$ & $\begin{array}{l}\text { Power and communication } \\
\text { center installed } 5 / 95\end{array}$ \\
\hline $\mathrm{EF}-17^{\mathrm{d}}$ & - & - & - & - & - & - & - & - \\
\hline
\end{tabular}


TABLE A.2 (Cont.)

\begin{tabular}{|c|c|c|c|c|c|c|c|c|}
\hline Site & $\begin{array}{l}\text { Elevation }{ }^{b} \\
\quad(\mathrm{~m})\end{array}$ & $\begin{array}{l}\text { Latitude, } \\
\text { Longitude } \\
\text { (deg) }\end{array}$ & $\begin{array}{l}\text { Surface } \\
\text { Type }\end{array}$ & $\begin{array}{l}\text { Flux } \\
\text { Stationc }\end{array}$ & SWATSC & SMOSC & $\begin{array}{l}\text { SIROS/ } \\
\text { SIRSc }\end{array}$ & Comment \\
\hline $\begin{array}{l}\text { Morris, OK } \\
\text { EF-18 }\end{array}$ & 217 & $\begin{array}{l}35.687 \mathrm{~N} \\
97.856 \mathrm{~W}\end{array}$ & $\begin{array}{l}\text { Pasture } \\
\text { (ungrazed) }\end{array}$ & $\begin{array}{l}\text { EBBR } \\
7 / 97\end{array}$ & $\begin{array}{l}\text { Yes } \\
9 / 96\end{array}$ & No & $\begin{array}{l}\text { Yes; } \\
\text { broad- } \\
\text { band } \\
\text { only } \\
5 / 24 / 96\end{array}$ & $\begin{array}{l}\text { Power and communication } \\
\text { center installed } 10 / 95\end{array}$ \\
\hline $\begin{array}{l}\text { El Reno, OK } \\
\text { EF-19 }\end{array}$ & - & - & $\begin{array}{l}\text { Pasture } \\
\text { (ungrazed) }\end{array}$ & EBBR & Yes & No & Yes & Implementation began in $5 / 97$ \\
\hline $\begin{array}{l}\text { Meeker, OK } \\
\text { EF-20 }\end{array}$ & 309 & $\begin{array}{l}35.564 \mathrm{~N} \\
96.988 \mathrm{~W}\end{array}$ & Pasture & $\begin{array}{l}\text { EBBR } \\
4 / 5 / 93\end{array}$ & $\begin{array}{l}\text { Yes } \\
2 / 8 / 96\end{array}$ & $\begin{array}{l}\text { Yes } \\
4 / 2 / 93\end{array}$ & Yes & $\begin{array}{l}\text { Power and communication } \\
\text { center installed } 10 / 94\end{array}$ \\
\hline $\begin{array}{l}\text { Okmulgee, } \\
\text { OK } \\
\text { EF-21 }\end{array}$ & 一 & $\begin{array}{l}\text { Location } \\
\text { identified }\end{array}$ & Forest & $\begin{array}{l}\text { ECOR } \\
4 / 97\end{array}$ & $\begin{array}{l}\text { Yes } \\
4 / 97\end{array}$ & $\begin{array}{l}\text { Yes } \\
4 / 97\end{array}$ & $\begin{array}{l}\text { Yes } \\
4 / 97\end{array}$ & $\begin{array}{l}\text { Lease signed } 2 / 97 \text {; installation } \\
\text { to begin in } 1997\end{array}$ \\
\hline $\begin{array}{l}\text { Cordell, OK } \\
\text { EF-22 }\end{array}$ & 465 & $\begin{array}{l}35.354 \mathrm{~N} \\
98.977 \mathrm{~W}\end{array}$ & $\begin{array}{l}\text { Rangeland } \\
\text { (grazed) }\end{array}$ & $\begin{array}{l}\text { EBBR } \\
4 / 5 / 93\end{array}$ & $\begin{array}{l}\text { Yes } \\
2 / 15 / 96\end{array}$ & No & $\begin{array}{l}\text { Yes } \\
4 / 26 / 95\end{array}$ & $\begin{array}{l}\text { Power and communication } \\
\text { center installed } 3 / 95\end{array}$ \\
\hline $\begin{array}{l}\text { Ft. Cobb, OK } \\
\text { EF-23 }\end{array}$ & 415 & $\begin{array}{l}35.153 \mathrm{~N} \\
98.461 \mathrm{~W}\end{array}$ & $\begin{array}{l}\text { Peanuts } \\
\text { (irrigated) }\end{array}$ & $\begin{array}{l}\text { ECOR } \\
12 / 96\end{array}$ & $\begin{array}{l}\text { Yes } \\
12 / 96\end{array}$ & No & $\begin{array}{l}\text { Yes } \\
12 / 96\end{array}$ & No lease agreement \\
\hline $\begin{array}{l}\text { Cyril, OK } \\
\text { EF-24 }\end{array}$ & 409 & $\begin{array}{l}34.883 \mathrm{~N} \\
98.205 \mathrm{~W}\end{array}$ & $\begin{array}{l}\text { Wheat } \\
\text { (gypsum } \\
\text { hill) }\end{array}$ & $\begin{array}{l}\text { ECOR } \\
8 / 25 / 95\end{array}$ & $\begin{array}{l}\text { Yes } \\
7 / 96\end{array}$ & $\begin{array}{l}\text { Yes } \\
8 / 25 / 95\end{array}$ & $\begin{array}{l}\text { Yes } \\
8 / 25 / 95\end{array}$ & $\begin{array}{l}\text { Power and communication } \\
\text { center installed } 7 / 95\end{array}$ \\
\hline $\begin{array}{l}\text { Seminole, OK } \\
\text { EF-25 }\end{array}$ & 277 & $\begin{array}{l}35.245 \mathrm{~N} \\
96.736 \mathrm{~W}\end{array}$ & Pasture & $\begin{array}{l}\text { EBBR } \\
12 / 97\end{array}$ & $\begin{array}{l}\text { Yes } \\
12 / 97\end{array}$ & $\begin{array}{l}\text { Yes } \\
12 / 97\end{array}$ & $\begin{array}{l}\text { Yes } \\
12 / 97\end{array}$ & $\begin{array}{l}\text { Power and communication } \\
\text { center installed } 11 / 96\end{array}$ \\
\hline
\end{tabular}


TABLE A.2 (Cont.)

\begin{tabular}{|c|c|c|c|c|c|c|c|c|}
\hline Site & $\begin{array}{c}\text { Elevationb } \\
(\mathrm{m})\end{array}$ & $\begin{array}{c}\text { Latitude, } \\
\text { Longitude } \\
\text { (deg) }\end{array}$ & $\begin{array}{l}\text { Surface } \\
\text { Type }\end{array}$ & $\begin{array}{c}\text { Flux } \\
\text { Stationc }\end{array}$ & SWATSc & SMOSc & $\begin{array}{l}\text { SIROS/ } \\
\text { SIRSc }\end{array}$ & Comment \\
\hline $\begin{array}{l}\text { Cement, OK } \\
\text { EF-26 }\end{array}$ & 400 & $\begin{array}{l}34.957 \mathrm{~N} \\
98.076 \mathrm{~W}\end{array}$ & Pasture & $\begin{array}{l}\text { EBBR } \\
6 / 10 / 92\end{array}$ & - & No & No & $\begin{array}{l}\text { Phone line (only) installed } \\
10 / 92\end{array}$ \\
\hline
\end{tabular}

a BSRN, Baseline Surface Radiation Network; EBBR, energy balance Bowen ratio; ECOR, eddy correlation; EF, extended facility; NEPA, National Environmental Policy Act; SIROS, solar and infrared radiation observing system; SIRS, solar and infrared station; SMOS, surface meteorological observation station; SWATS, soil water and temperature system.

b Above sea level.

c Date indicates actual or scheduled installation date.

d This extended facility is a placeholder site, for possible expansion, if required. 
TABLE A.3 Locations and Status of Intermediate Facilities

\begin{tabular}{|c|c|c|c|c|c|}
\hline Site & $\begin{array}{l}\text { Elevation } b \\
\quad(m)\end{array}$ & $\begin{array}{l}\text { Latitude, } \\
\text { Longitude } \\
\text { (deg) }\end{array}$ & $\begin{array}{l}\text { Surface } \\
\text { Type }\end{array}$ & $\begin{array}{c}\text { 915-MHz } \\
\text { Profiler and } \\
\text { RASSc }\end{array}$ & Comment \\
\hline $\begin{array}{l}\text { Beaumont, KS } \\
\text { IF-1 }\end{array}$ & 525 & $\begin{array}{l}37.626 \mathrm{~N} \\
96.538 \mathrm{~W}\end{array}$ & Rangeland & $\begin{array}{l}\text { Yes } \\
9 / 96\end{array}$ & $\begin{array}{l}\text { Power and communication installed } \\
9 / 96\end{array}$ \\
\hline $\begin{array}{l}\text { Medicine Lodge, KS } \\
\text { IF-2 }\end{array}$ & 585 & $\begin{array}{l}37.280 \mathrm{~N} \\
98.933 \mathrm{~W}\end{array}$ & Rangeland & $\begin{array}{l}\text { Yes } \\
9 / 96\end{array}$ & $\begin{array}{l}\text { Power and communication installed } \\
9 / 96\end{array}$ \\
\hline $\begin{array}{l}\text { Meeker, OK } \\
\text { IF-3 }\end{array}$ & 300 & $\begin{array}{l}35.550 \mathrm{~N} \\
96.920 \mathrm{~W}\end{array}$ & Grass & $\begin{array}{l}\text { Yes } \\
9 / 96\end{array}$ & $\begin{array}{l}\text { Power and communication installed } \\
9 / 96\end{array}$ \\
\hline
\end{tabular}

a IF, intermediate facility; RASS, radio acoustic sounding system.

b Above sea level.

c Date indicates actual installation date. 
TABLE A.4 Locations and Status of Boundary Facilities ${ }^{a}$

\begin{tabular}{|c|c|c|c|c|c|c|c|c|}
\hline Site & $\begin{array}{l}\text { Elevation } b \\
(\mathrm{~m})\end{array}$ & $\begin{array}{l}\text { Latitude, } \\
\text { Longitude } \\
\text { (deg) }\end{array}$ & $\begin{array}{c}\text { Surface } \\
\text { Type }\end{array}$ & $\mathrm{BBSS}^{\mathrm{c}}$ & $\mathrm{MWR}^{\mathrm{c}}$ & Vceil & AERI & Comment \\
\hline $\begin{array}{l}\text { Hillsboro, KS } \\
\text { BF-1 }\end{array}$ & 441 & $\begin{array}{l}36.071 \mathrm{~N} \\
99.218 \mathrm{~W}\end{array}$ & Grass & $\begin{array}{l}\text { Yes } \\
1 / 18 / 94\end{array}$ & $\begin{array}{l}\text { Yes } \\
1 / 18 / 94\end{array}$ & - & No & $\begin{array}{l}\text { Temporary power and } \\
\text { communication installed } \\
12 / 93\end{array}$ \\
\hline $\begin{array}{l}\text { Hillsboro, KS } \\
\text { BF-1 }\end{array}$ & 447 & $\begin{array}{l}38.305 \mathrm{~N} \\
97.301 \mathrm{~W}\end{array}$ & Grass & $\begin{array}{l}\text { Yes } \\
9 / 28 / 94\end{array}$ & $\begin{array}{l}\text { Yes } \\
9 / 28 / 94\end{array}$ & $\begin{array}{l}\text { Yes } \\
8 / 97\end{array}$ & No & $\begin{array}{l}\text { Relocation and temporary } \\
\text { power and communication } \\
\text { installed } 9 / 94 \text {; permanent } \\
\text { power, communication, and } \\
\text { grounding mat installed } \\
3 / 96 ; \mathrm{T}-1 \text { line installed } 4 / 96\end{array}$ \\
\hline $\mathrm{BF}-2$ & - & Unspecified & 一 & - & - & - & No & - \\
\hline $\mathrm{BF}-3$ & - & Unspecified & - & - & - & - & No & - \\
\hline $\begin{array}{l}\text { Vici, OK } \\
\text { BF-4 }\end{array}$ & 648 & $\begin{array}{l}36.071 \mathrm{~N} \\
99.218 \mathrm{~W}\end{array}$ & Grass & $\begin{array}{l}\text { Yes } \\
1 / 18 / 94\end{array}$ & $\begin{array}{l}\text { Yes } \\
1 / 18 / 94\end{array}$ & - & No & $\begin{array}{l}\text { Temporary power and } \\
\text { communication installed } \\
12 / 93\end{array}$ \\
\hline $\begin{array}{l}\text { Vici, OK } \\
\text { BF-4 }\end{array}$ & 622 & $\begin{array}{l}36.071 \mathrm{~N} \\
99.204 \mathrm{~W}\end{array}$ & Grass & $\begin{array}{l}\text { Yes } \\
10 / 3 / 94\end{array}$ & $\begin{array}{l}\text { Yes } \\
10 / 3 / 94\end{array}$ & $\begin{array}{l}\text { Yes } \\
8 / 97\end{array}$ & No & $\begin{array}{l}\text { Relocation and temporary } \\
\text { power and communication } \\
\text { installed } 9 / 94 ; \text { permanent } \\
\text { power, communication, and } \\
\text { grounding mat installed } \\
3 / 96 \text {; T-1 line installed } 4 / 96\end{array}$ \\
\hline $\begin{array}{l}\text { Morris, OK } \\
\text { BF-5 }\end{array}$ & 18 & $\begin{array}{l}35.682 \mathrm{~N} \\
95.862 \mathrm{~W}\end{array}$ & Grass & $\begin{array}{l}\text { Yes } \\
1 / 18 / 94\end{array}$ & $\begin{array}{l}\text { Yes } \\
1 / 18 / 94\end{array}$ & & No & $\begin{array}{l}\text { Temporary power and } \\
\text { communication installed } \\
12 / 93\end{array}$ \\
\hline
\end{tabular}


TABLE A.4 (Cont.)

\begin{tabular}{|c|c|c|c|c|c|c|c|c|}
\hline Site & $\begin{array}{l}\text { Elevation }{ }^{b} \\
(\mathrm{~m})\end{array}$ & $\begin{array}{l}\text { Latitude, } \\
\text { Longitude } \\
\text { (deg) }\end{array}$ & $\begin{array}{l}\text { Surface } \\
\text { Type }\end{array}$ & $\mathrm{BBSS}^{\mathrm{c}}$ & $M W R c$ & Vceil & AERI & Comment \\
\hline $\begin{array}{l}\text { Morris, OK } \\
\text { BF-5 }\end{array}$ & 217 & $\begin{array}{l}35.688 \mathrm{~N} \\
95.856 \mathrm{~W}\end{array}$ & Grass & $\begin{array}{l}\text { Yes } \\
10 / 6 / 94\end{array}$ & $\begin{array}{l}\text { Yes } \\
10 / 6 / 94\end{array}$ & $\begin{array}{l}\text { Yes } \\
8 / 97\end{array}$ & No & $\begin{array}{l}\text { Relocation and temporary } \\
\text { power and communication } \\
\text { installed } 9 / 94 ; \text { permanent } \\
\text { power, communication, and } \\
\text { grounding mat installed } \\
3 / 96 ; T-1 \text { line installed } 4 / 96\end{array}$ \\
\hline $\begin{array}{l}\text { Purcell, OK } \\
\text { BF-6 }\end{array}$ & 344 & $\begin{array}{l}34.969 \mathrm{~N} \\
97.415 \mathrm{~W}\end{array}$ & Grass & $\begin{array}{l}\text { Yes } \\
9 / 23 / 94\end{array}$ & $\begin{array}{l}\text { Yes } \\
9 / 23 / 94\end{array}$ & $\begin{array}{l}\text { Yes } \\
8 / 97\end{array}$ & $\begin{array}{l}\text { Yes } \\
10 / 97\end{array}$ & $\begin{array}{l}\text { Permanent power, } \\
\text { communication, and } \\
\text { grounding mat installed } \\
3 / 96 ; \mathrm{T}-1 \text { line installed } 4 / 96\end{array}$ \\
\hline
\end{tabular}

a AERI, atmospherically emitted radiance interferometer; BBSS, balloon-borne sounding system; BF, boundary facility; MWR, microwave radiometer; Vceil, Vaisala ceilometer.

b Above sea level.

c Date indicates actual installation date. 